\title{
The imperial roots of global trade
}

\section{Gunes Gokmen ${ }^{1} \cdot$ Wessel N. Vermeulen ${ }^{2} \cdot$ Pierre-Louis Vézina ${ }^{3}$}

Published online: 8 February 2020

(c) The Author(s) 2020

\begin{abstract}
Throughout history empires facilitated trade within their territories by building and securing trade and migration routes, and by imposing common norms, languages, religions, and legal systems, all of which led to the accumulation of imperial capital. In this paper, we collect novel data on the rise and fall of empires over the last 5000 years, construct a measure of accumulated imperial capital between countries, and estimate its relationship with trade patterns today. Our measure of imperial capital has a positive and significant effect on trade beyond potential historical legacies such as sharing a language, a religion, a legal system, or links via natural trade and invasion routes. This suggests a persistent and previously unexplored influence of long-gone empires on current trade.
\end{abstract}

Keywords Imperial capital · Empires · Trade $\cdot$ Long-run persistence $\cdot$ Gravity

JEL Classification F14 · N70

\section{Introduction}

Modern life flows on an ever-rising river of trade; if we wish to understand its currents and course, we must travel up its headwaters to commercial centers with names like Dilmun and Cambay, where its origins can be sought, and its future imagined.

William J. Bernstein in A Splendid Exchange (2008)

Pierre-Louis Vézina

pierre-louis.vezina@kcl.ac.uk

Gunes Gokmen

gunesgokmen@gmail.com

Wessel N. Vermeulen

wessel.vermeulen@ncl.ac.uk

1 Lund University, Lund, Sweden

2 Newcastle University, Newcastle upon Tyne, UK

3 King's College London, London, UK 
The greatest expansions of world trade have tended to come not from the bloodless tâtonnement of some fictional Walrasian auctioneer but from the barrel of a Maxim gun, the edge of a scimitar, or the ferocity of nomadic horsemen.

Findlay and O'Rourke in Pwower and Plenty (2007)

Today's countries emerged from hundreds of years of conquests, alliances, and downfalls of empires. The long-run persistence of such historical episodes has been the focus of a new strand of literature in economics. For instance, Oto-Peralías and Romero-Ávila (2016) show how the Reconquista, i.e. the series of conquests that led to the fall of the last Islamic state in Spain in the 15th century, explains differences in Spanish regional economic development today. Another example is Wahl (2017) who argues that the persistence of Roman roads explains part of the development advantage of the formerly Roman parts of Germany. ${ }^{1}$

The aim of this paper is to uncover how the rise and fall of empires throughout history, from the Afsharid Dynasty to the British Empire, still influence world trade. To that end, we collect novel data on 5000 years of imperial history, construct a measure of accumulated imperial capital between countries, and estimate its relationship with trade patterns today.

Imperial capital can be thought of as norms, institutions, and networks that emerged during empires to facilitate trade and that may outlive empires. ${ }^{2}$ Throughout history, many empires were essentially about facilitating trade. For instance, in its review of Bernstein (2008), The Economist (2008) explains how the Athenian Empire was established to secure food trade:

The Athenians were driven by the dictates of trade to create, first, a powerful navy, and then, an empire. [...] Low rainfall and a mountainous topography made it impossible for farmers to produce enough grain for a growing and increasingly city-based population. The Spartans and their allies looked west to Sicily, but the Athenians increasingly relied on access to the breadbasket of Pontus (modern Ukraine). This, in turn, meant keeping open those narrowest of choke points: the Dardanelles (to the Greeks, the Hellespont) and the Bosphorus. Other states in the region were just as dependent on the trade with Pontus, and were, therefore, prepared to contribute to the costs of Athenian naval operations. Before long, this "coalition of the willing" evolved into the Athenian Empire.

Findlay and O'Rourke (2009) provide many other instances of how facilitating trade was central to empires. The conquests of the Mongol Empire, for example, stabilized long-distance trade across Central Asia during a century known as Pax Mongolica. The Byzantine

\footnotetext{
1 Other examples include Acemoglu et al. (2001) and Easterly and Levine (2016), who trace the role of colonial institutions in explaining the prosperity of today's countries, Nunn (2008), who shows that the slave trade had long-lasting damaging effects on African development, and Grosfeld and Zhuravskaya (2015) who show that three vanished empires' different religious practices and ideals persist in today's Poland. See Michalopoulos and Papaioannou (2017) for a comprehensive collection of short essays on the long shadow of history, Nunn (2009) and Spolaore and Wacziarg (2013) for reviews of this literature, and Galor (2011) for a comprehensive account of deep-rooted factors in comparative development.

2 The concept was introduced by Head et al. (2010) who show that despite a gradual deterioration of trade links, colonial links still explain part of today's trade flows. They suggest that a form of trade-enhancing capital that depreciates slowly over time could explain this persistence. A few studies on the role of history in world trade have also suggested that historical events that allow costs to be sunk can be associated with a persistent level of trade (Eichengreen and Irwin 1998).
} 
Empire organized trade across the Mediterranean and the Black Sea using imperial monopolies, strict controls, and written trade agreements known as Chrysobull. ${ }^{3}$ Other examples include the expansion of markets, trade, and specialization that occurred in China during the Song Dynasty, notably thanks to an extensive network of canals and waterways, and the lucrative trade in furs, silver and silk between the East and the West, which was made possible by the Vikings taking control of the Russian river systems. Perhaps even more obvious is the blend of trade, plunder, and settlement associated with colonial empires. The East India Company, initially only established for the pursuit of trade opportunities, was key to the creation of the British Empire in India. Colonial imperialism is indeed often based on the idea that trade follows the flag, or that trade flourishes only under a harmonized polity. Colonial empires doubled trade within their controlled territories between 1870 and 1913 by lowering transaction costs and establishing preferential trade policies (Mitchener and Weidenmier 2008).

We can, therefore, think of empires as entities that facilitated trade within their controlled territories by building and securing trade and migration routes, and by spreading common norms, languages, religions, and legal systems. This led to the accumulation of imperial capital such as physical capital, e.g. roads, railway lines or canals; common institutions, e.g. common legal systems; business networks, e.g. commercial diasporas such as the Gujaratis in the British Empire; or cultural capital, e.g. common language, religion, and trust. These formal and informal institutions persist through time and affect today's global economy. The Byzantine empire, for example, played a big role in the spread of roman law which still influences many legal systems today, and in the cultural spread of orthodox Christianity throughout the Byzantine commonwealth, from modern-day Greece to southwestern Russia. Historical Habsburg-Empire regions have higher current trust and lower corruption than neighboring regions, most likely due to the empire's well-respected administration (Becker et al. 2016), and countries of the Habsburg Empire trade significantly more with one another than what is predicted by the gravity model (Rauch and Beestermoller 2014). Similarly, Grosjean (2011) shows that 16th-18th century European empires explain social trust differences across countries. The formation of imperial capital may also come from the act of trading itself. Jha (2013) shows that local institutions that emerged to support inter-ethnic medieval trade have resulted in a sustained legacy of ethnic tolerance in South Asian port towns. ${ }^{4}$

To empirically study the legacy of empires, we collect novel historical data on the territories controlled by 168 empires, from the Achaemenid Empire to the Yuan and Zand Dynasties. We then create an imperial capital measure at the country-pair level. ${ }^{5}$ Assuming that imperial capital grows between two countries when they are both controlled by the same empire but also depreciates with time, our measure takes into account all imperial history by considering years in and years since all common empires.

One way to understand our imperial capital measure is as a bilateral index akin to the state history index introduced by Bockstette et al. (2002) and extended by Borcan et al.

\footnotetext{
3 A Chrysobull, or golden bull, was a written trade agreement, sealed with gold, that established trade preferences across provinces of the empire. In 1082, for example, the Byzantine emperor issued a chrysobull to give Venetian merchants trade preferences. The Byzantine empire also had a trade manual, the book of Eparch, detailing merchant guilds, import regulations, and the setting of prices.

4 More examples on the emergence of such formal and informal trade-enhancing institutions can be found in Greif (2006).

5 We use a wide array of sources for data collection. These are empire-country specific and are listed in our online database. We provide more details on our data construction in the next section.
} 
(2018). While the state history index captures the history of individual state institutions in a location (or the characteristics of people who used to live there at a certain point in time as in Putterman and Weil 2010), our measure captures shared formal and informal institutions and a common heritage between locations. Our imperial capital measure can hence function as a historically grounded indicator that captures the strength of a common past between countries today.

We include our measure of imperial capital into a gravity model to estimate its relationship with trade today. ${ }^{6}$ Importantly, to isolate the effect of imperial capital from other geographic factors such as mountains, deserts or large water bodies that may affect both past empire expansions and today's trade patterns, we account for a comprehensive measure of geographic barriers. To do so, we calculate the number of hours it would take a human to travel an optimal route between two countries (à la Özak 2010, Human Migration Index), and control for it in our regressions.

We find that long-gone empires have indeed left their mark on today's trade patterns. A $10 \%$ increase in imperial capital is associated with an increase in bilateral trade of at least $1.15 \% .^{7}$ Doubling imperial capital corresponds to an increase in trade around $10 \%$. Among countries with non-zero imperial capital, moving from a minimal imperial capital to a maximum one brings about a $36 \%$ increase in trade. Our findings are similar when we test alternative measures of imperial capital such as an indicator of whether two countries were ever part of the same empire, the number of years the two countries were in joint empires, and the number of joint empires they have been part of. Imports from countries that were once in a common empire are, on average, 55\% larger than from other countries.

We also build a measure of deep imperial capital, i.e. imperial capital that depends on three characteristics of empires: a centralized administration, a centralized religion, and a monopoly on coin minting. We find that deep imperial capital, accumulated during empires particularly conducive to trade-enhancing harmonization, has even more explanatory power than our more general baseline measure of imperial capital. We additionally explore the heterogeneous effects across colonial and non-colonial imperial capitals and find that the latter matters almost as much in explaining today's trade.

We then investigate to what extent institutional and cultural legacies such as sharing a legal system, a language, or a religion may explain the persistence of past empires. We show that part of the relationship between imperial capital and trade (up to 50\%) is explained by these historical bilateral affinity measures. Thus, a common imperial heritage

\footnotetext{
${ }^{6}$ Economists have been trying to understand international trade patterns at least since Adam Smith published The Wealth of Nations in 1776. A series of explanations from comparative advantage to economies of scale and love of variety have been proposed and tested in the last 50 years (see, for example, Davis 2000; Davis and Weinstein 2003; Chor 2010). A particularly robust empirical finding has been the gravity model of trade, which links trade between two countries to the geographic distance between them and to other bilateral trade costs such as diverging institutions or cultures (Tinbergen 1962; Head and Mayer 2014, 2013).

7 One needs to be cautious in causally interpreting our estimates. Despite our efforts to control for the geographic factors that may be behind both trade and empire formation, omitted factors related to trade potential may still explain part of the relationship we document. In robustness checks, we attempt to attenuate this concern. We show that placebo empires determined by geography are not associated with trade today. In one specification, we include both an empire dummy and our measure of imperial capital to explain trade. This gets us close to a backdoor-criterion identification, i.e. once we control for selection into empires with the dummy variable, the intensity of treatment (imperial capital) is not affected by the omitted factors that affect both trade and empire formation. Nevertheless, it is important to keep this caveat in mind when interpreting the effect of imperial capital.
} 
is part of the reason why countries share institutions and culture, and this, in turn, has a persistent effect on trade.

While infrastructure such as roads (Michaels 2008), railways (Donaldson 2018), or telegraphs (Steinwender 2018) do promote trade, Head and Mayer (2013) point out that transport costs (and tariffs) do not account for most of the trade costs associated with borders and distance. Instead, they point to cultural and informational frictions as the main culprits. This is why cultural similarity (Felbermayr and Toubal 2010; Gokmen 2017) and transnational networks (Rauch and Trindade 2002) are so important to trade. Indeed, the latter facilitate trade by reducing contract enforcement costs and by providing information about trading opportunities (Rauch 2001). Our results suggest that imperial capital might play a similarly important role in reducing these frictions that inhibit international trade. ${ }^{8}$

Our paper is the first to estimate the relationship between all past empires and today's trade patterns. While researchers have highlighted the role of colonial history in current trade (Head et al. 2010), we add to the literature by demonstrating the influence of the entire universe of empires, particularly non-colonial ones, since 3000 BC. Our new comprehensive dataset documents empire-country relations for the whole world and throughout all history. A valuable contribution is also to make the entire universe of empire-country history available to researchers. We also build a dynamic indicator of imperial capital that accounts for both time in and time since joint empires, unlike previous studies on the effect of colonial empires which usually rely on dummy indicators. This paper also advances our understanding of historical legacies by focusing on the case of international trade. While there is much evidence that empires played an important role in shaping institutions and culture, we highlight how empires also shaped bilateral affinities between countries and how these, in turn, influence world trade, which we know is a major driver of economic growth (Feyrer 2009; Pascali 2017; Donaldson 2018; Wahl 2016).

The rest of the paper proceeds as follows. The next section presents our data and empirical strategy. In Sect. 3, we discuss the results. Sect. 4 concludes.

\section{Data and empirical strategy}

\subsection{Empire data and imperial capital}

To construct our measure of imperial capital, we collect data on the geographic expansion and shrinkage of 168 empires from a wide array of sources. ${ }^{9}$ Our full list of empires and sources are available online at https://www.wnvermeulen.com/empires/. Some key sources are Turchin (2009), Euratlas-Nüssli, the Digital Atlas of Roman and Medieval Civilizations

\footnotetext{
8 This does not rule out that imperial legacies also affect trade via infrastructure such as road networks. We know from Volpe Martincus et al. (2017) that roads from the pre-columbian Inca Empire explain today's roads locations and in turn Peruvian firms' exports. Also, Pinna and Licio (2017) argue Roman roads have a similar impact on Italy's foreign trade, and Fluckiger et al. (2019) argue that the Roman transport network has effects on the intensity of bilateral investment today.

9 We follow, as closely as possible, Encyclopedia Britannica's definition of an empire: Empire, major political unit in which the metropolis, or single sovereign authority, exercises control over territory of great extent or a number of territories or peoples through formal annexations or various forms of informal domination. We also attempt to be as encompassing as possible. We acknowledge that researchers use various definitions in practice (see, for example Turchin 2009), however, different selection criteria are unlikely to alter our results.
} 
from Harvard, the Centennia Historical Atlas, the New Cambrigde Economic History Atlas by Darby and Fullard, Encyclopedia Britannica, the Encyclopedia of Empire (Mackenzie 2016), as well as a range of empire specific sources. ${ }^{10}$

This data collection allows us to match each empire's territory to today's countries, whether covered in whole or partially, and during which years. For example, the Empire of Trebizond covered parts of today's Georgia, Turkey and Ukraine from 1204 to 1461. The Great Moravian Empire was spread over today's Czechia and Slovakia from 833 to 906, while it also covered parts of Poland from 877 to 894. Table 20 in "Appendix 3" gives an overview of this dataset. ${ }^{11}$

Based on our database, we build an indicator of imperial capital capturing both time in and time since a joint empire, to fully capture the heterogeneity of imperial legacies. ${ }^{12}$ We conjecture that spending 100 years in a joint empire 2000 years ago does not matter as much for today's trade relationships as spending 100 years in the Habsburg Empire only 200 years ago. Our measure of imperial capital, thus, needs to discount the number of years spent in an empire by the time elapsed since then. Hence, we assume that imperial capital builds up in times of empires, when trading relationships are formed, common institutions established, and roads built, but that this capital, like all forms of capital, depreciates over time.

To construct our measure of imperial capital, we are inspired by the state history index introduced by Bockstette et al. (2002) and extended by Borcan et al. (2018). We build it such that in times of a common empire imperial capital increases by 1 unit per year, and over time it depreciates by $0.1 \%$ per year. ${ }^{13}$

Algebraically, we can represent the dynamics of imperial capital, $E_{i j, t}$, as follows:

$$
\begin{aligned}
& E_{i j, t}=E_{i j, t-1} \times(1+\delta)^{-1}+V_{i j, t}, \\
& E_{i j, 0}=0,
\end{aligned}
$$

\footnotetext{
${ }^{10}$ We would like to note that Wikipedia has been a great resource for our initial exploration and data collection, notably the "list of empires". Other online sources such as Running Reality, an on-line application that maps the history of human civilization from 3000 BC to today, and WorldStatesmen.org, an online encyclopedia of the leaders of nations and territories, have been very useful as well. On top of multiple rounds of verification of each empire-country data entry by three specialist research assistants, we also stress-tested our data set via emails to more than 180 historians across the world, and with a dozen of faceto-face meetings with historians at our universities. This was a serious effort of crowd-sourcing. With the full dataset now online, we invite researchers to explore the data, make suggestions for improvement, and use it freely in their own research.

${ }^{11}$ We do not differentiate between the size of the countries' areas covered by the empires. One reason for this choice is that the location of empire boundaries is sometimes imprecise. Another is that we prefer not to assume an arbitrary cutoff to the size of a country's area covered by an empire for that country to be considered part of an empire. While larger areas could be associated with stronger imperial capital today, distinct cultural or ethnic groups in border regions could also have a large effect on cross-border trade. Hence, we include countries as part of empire even when only a part of the country's area is covered by the empire.

12 We can create various measures of shared imperial past at the country-pair level, such as an indicator of whether two countries were ever contemporaneously part of the same empire, the number of years the two countries were in joint empires, or the number of joint empires they have been part of. Our aim here is for our measure to simultaneously account for both time in and time since a joint empire.

${ }^{13}$ We follow Borcan et al. (2018) in choosing these accumulation and decay parameters. Borcan et al. (2018) suggest a decay rate of $5 \%$ per period of 50 years, which is equivalent to $0.1 \%$ per year. We use a range of different decay rates, from 0.01 to $1 \%$, in robustness checks (see Table 17 in the "Appendix 1").
} 
for country pair $i j$ where $V_{i j, t}$ is a vector of length $T$ indicating whether a country pair $i j$ is in a common empire in year $t$ or not. ${ }^{14}$ The parameter $\delta$ is the annual depreciation rate of imperial capital.

Implicitly, in building this measure, we assume that every empire contributes identically to imperial capital. Yet, different empires with different institutions or different deepness may contribute differently to the accumulation of imperial capital. To capture this potential heterogeneity, we also build a measure of deep imperial capital, taking into account three features of empires that may be associated with long-lasting imperial capital. These are: (1) a centralized administration (king), (2) a central and dominant religion (god), (3) a monopoly on the minting of coins (although these did not exist before $700 \mathrm{BCE}$ ) (coin). We conjecture that these three characteristics are likely to be associated with institutions and trade, and thus, conducive to the accumulation of imperial capital.

A centralized administration is presumably linked to the development and harmonization of formal institutions and infrastructure. One example here is the Annona, i.e. the system used by the central government in the Roman empire to supply its cities with grain imported from North Africa, using some 5000 ships in three rotations (Laiou and Morrisson 2007). Another example is the vast road network built across the Inca empire using tunnels and suspension bridges. The latter's use was strictly limited to the government who controlled long-distance trade. Not all empires had an all-powerful centralized administration however. The Kingdom of Funan in Southeast Asia for instance relied on a mandala system of governance, i.e. a network of states with diffuse political power. As for the spread of norms and culture, they might have been facilitated by a dominant religion. The Inca empire might have contributed to the building of mutual trust through cultural practices such as ayni, i.e. a concept of reciprocity in exchange, based on Inca cosmology, and still practiced among tribes in Peru, Ecuador, and Bolivia. The cultural spread of orthodox Christianity throughout the Byzantine commonwealth, from modern-day Greece to southwestern Russia, can also explain part of the mutual trust between these countries today. The role of coin minting monopolies in trade reflects more directly the role of the imperial government in controlling and fomenting trade across regions. The Byzantine coin is known as the dollar of the middle ages for this reason (Lopez 1951).

We thus build our measure of deep imperial capital such that it increases by 1 in a year of common empire if these three features are present. If the empire has no such feature, there is no capital accumulation. If it has one feature out of 3 , capital increases by 0.33 , and if it has 2 , by $0.66 .^{15}$

We also build a measure of imperial capital that takes into account only the countries' relationship with the metropole, the country where the central authority was located. The idea here is that the metropole played a primary role in spreading imperial capital to its provinces while the integration of provinces together did not occur to the same extent. The colonial relationship dummy often included in gravity regressions similarly usually captures only the relationships with the metropole.

Figure 1 illustrates the evolution of these three different measures of imperial capital between Egypt and Iraq. The two countries have been part of many joint empires over the last 3000 years including the Neo Babylonian Empire, the Umayyad Caliphate, and the Ottoman Empire. As explained above, we hypothesize that imperial capital grew during

\footnotetext{
${ }^{14} T=4500-1$, for the number years from present day to the first empire, 2500BC, such that the $V_{i j, 1}$ corresponds to the year 2500BC for country-pair $i j$, and $V_{i j, T}$ the last year of simulation (2000).

15 In Eq. (1), $V_{i j, t}$ takes the values of $0,0.33,0.66$, and 1, to reflect the deep capital characteristics.
} 


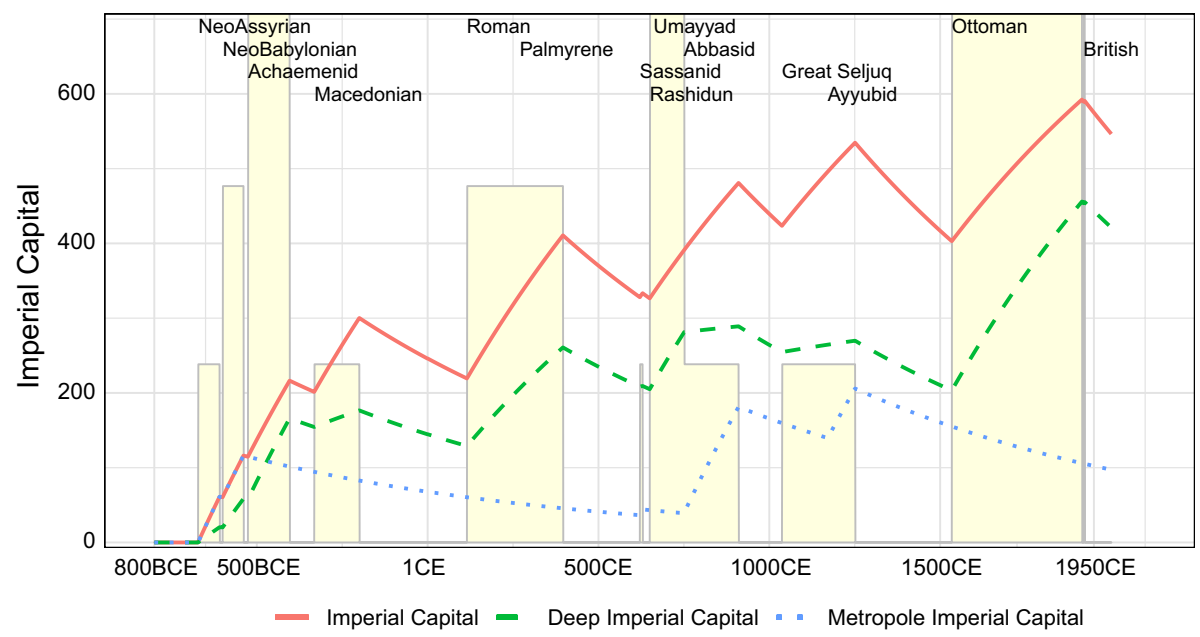

Fig. 1 The dynamics of imperial capital between Egypt and Iraq. Notes Example of imperial capital for two countries, Egypt and Iraq. Imperial capital grows by one unit for each year that the two current day countries are, at least partially, covered by a common empire. Capital depreciates continuously by $0.1 \%$ per year, which is roughly $5 \%$ per 50 years. The deep imperial capital line differentiates capital accumulation using three empire characteristics, summarized by 'King', 'God', and 'Coin'. Each characteristic gives an imperial capital amount of 0.33 per year, with the maximum of 1 for all three characteristics. The metropole line takes into account only the years when one of the two countries is considered the metropole, or the administrative center, of the empire

those years while it depreciated over time. The bars show the periods of common empire, and their height captures the number of deep empire characteristics. For example, since the metropole of the Ottoman empire, present-day Turkey, was neither in Egypt nor in Irak, Metropole imperial capital does not increase during that empire. The slow erosion of imperial capital shows how it can persist over time and still influence trade today.

Figure 2 shows the inflows of imperial capital for the world as a whole over time. In other words, it shows how many country-pairs see their common imperial capital increase each year, and how imperial capital has grown over time with the inclusion of more and more countries. It also illustrates how most accumulated imperial capital is deep imperial capital. What this figure clarifies is that empires became a world phenomenon around 500BCE. Before that time, empires existed but were limited at the global level, which does not imply that such early empires are irrelevant for the countries that were part of it. After 500BCE, we see a number of expansions and declines. The period 600-1400 shows a level of stability at the global level, and after a short trough, we see a massive growth that we can associate to the European colonial expansion. Colonial empires collapsed around 1950, and no new empires emerged after that. We choose not to include more modern federative entities such as the Soviet Union or the European Union. In our data, imperial capital, thus, depreciates until 2000.

Table 1 gives examples of imperial capital between countries that have a shared imperial history. The pair with the highest imperial capital is Syria-Turkey. France and Germany have shared 9 empires in the past, yet, their imperial capital is below that of India and Sri Lanka, which have shared only 5 empires. This illustrates how the number of shared empires may not matter that much if these were short-lived and a long time ago. We also 
have pairs like Canada and France, which have been part of only 1 common empire but have a high level of imperial capital left.

The distribution of our measure of imperial capital is illustrated in Fig. 3, which also shows the negative relationship between imperial capital and bilateral geodesic distance across countries. While more than $70 \%$ of country-pairs have no imperial capital, 9399 country-pairs have accumulated some of it since 2350 BCE.

\subsection{Trade data and gravity variables}

The workhorse model of trade relations between countries is the gravity model, which links trade between two countries to the geographic distance between them and to other bilateral trade costs such as diverging institutions or cultures (Tinbergen 1962; Head and Mayer 2013, 2014). The model can be summarized as follows:

$$
\operatorname{asinh}\left(m_{i j}\right)=\beta_{E} \operatorname{asinh}\left(E_{i j}\right)+\beta_{X}\left(X_{i j}\right)+\alpha_{i}+\sigma_{j}+\epsilon_{i j},
$$

where $m_{i j}$ is the average imports of country $i$ from country $j$ in the $2000 \mathrm{~s} .{ }^{16}$ We take the inverse hyperbolic sine rather than the log of imports to include country-pairs with zero bilateral trade. ${ }^{17}$ The parameters $\alpha_{i}$ and $\sigma_{j}$ are importer and exporter fixed effects. The variable $\mathrm{E}_{i j}$ is the amount of imperial capital accumulated between countries $i$ and $j$. The set of baseline bilateral control variables, $X_{i j}$, includes contiguity, distance, and differences in latitudes and longitudes. We also control for the ease of human mobility using an index $\grave{a}$ la Ömer Özak's Human Migration Index (Özak 2010), which we detail in the next section. These control for the tendency of natural obstacles such as mountains and deserts to act as a barrier to trade and empire expansion, as many empires expanded geographically by pushing their borders further and further. We follow Abadie et al. (2017) and cluster standard errors, $\epsilon_{i j}$, by country-pairs. ${ }^{18}$

All our data that is not related to empires is from standard sources. Trade data comes from UN Comtrade. Other variables such as common legal system, language, religion, and trade agreements, among others, are taken from the CEPII database (Mayer and Zignago 2011).

\subsection{Accounting for geographic barriers}

While the literature most often uses bilateral geodesic distance to capture trade costs between countries in gravity equations, we can be more precise in measuring the geographic factors that can act as barriers to trade and empire expansion.

\footnotetext{
16 The choice of an average for the 2000s maximises the country coverage compared to picking any year in the 2000s. Doing the latter does not change the results.

17 The asinh function is defined at zero and is otherwise similar to the natural logarithm function. We thus interpret our coefficients as proportional effects, i.e. as in log-log models. See Burbidge et al. (1988); MacKinnon and Magee (1990) for details on the asinh function, Kristjánsdóttir (2012) for an application to the gravity equation, and Card and DellaVigna (2017) for another example.

18 Here we deem what is important is to cluster at the level of our treatment. Since imperial capital is symmetric, we have two observations treated by the same level of imperial capital. Our identifying variation is thus half the size of our number of observations.
} 


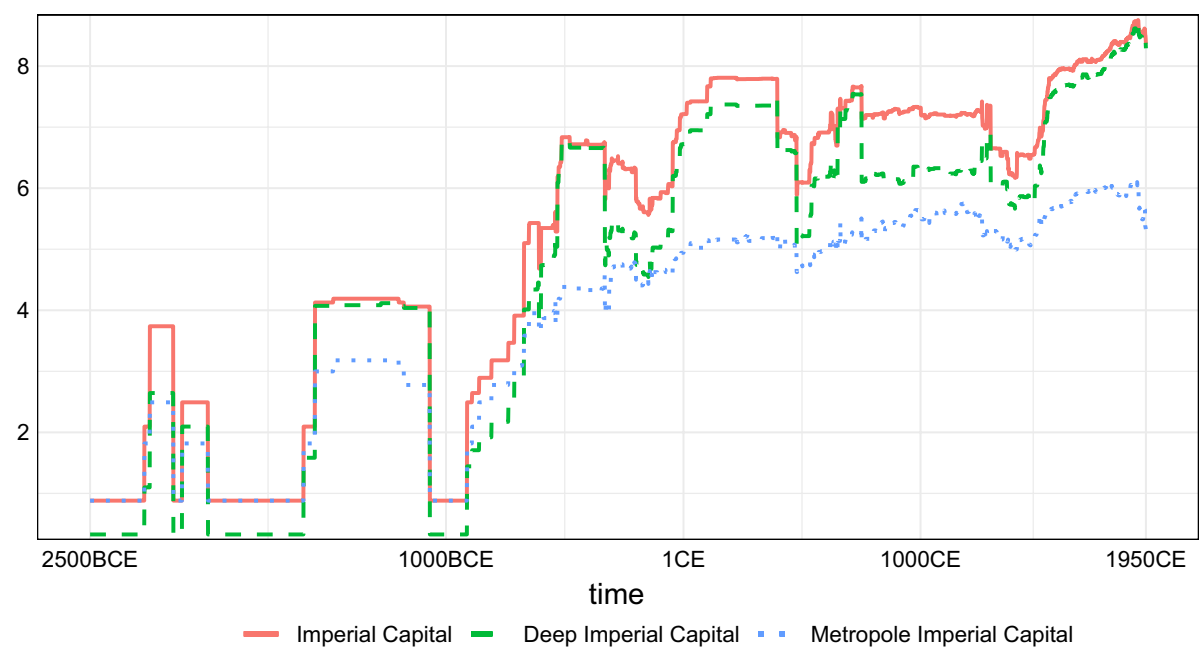

Fig. 2 Inflows of imperial capital across the world over time. Notes The figure shows the sum of imperial capital additions by year, for the entire world (in asinh). It measures the new capital globally gained. An increase indicates existing empires expanding or new empires emerging, with the consequence that more countries are associated to historic empires. The differentiation between 'deep capital' and 'metropole' is as given in the text and illustrated in Fig. 1

Table 1 Examples of imperial capital between countries

\begin{tabular}{llcl}
\hline Country pair & & Nb of empires & Imperial capital \\
\hline Syria & Turkey & 27 & 7.48 \\
Greece & Bulgaria & 10 & 7.43 \\
India & Sri Lanka & 5 & 7.43 \\
Israel & Egypt & 20 & 7.42 \\
Iran & Iraq & 26 & 7.39 \\
France & Germany & 9 & 7.15 \\
Myanmar & Russia & 4 & 6.28 \\
Canada & France & 1 & 5.78 \\
Morocco & Equatorial Guinea & 1 & 4.43 \\
Guatemala & Belize & 1 & 3.03 \\
\hline
\end{tabular}

If two countries are separated by a natural border such as a mountain range, or large water bodies, trade costs as well as invasion costs are likely to be high. Such geographic barriers may thus reduce the likelihood that two countries trade and that they were ever part of a joint empire. They may explain the geography of past empire expansion and still directly impact trade today. Therefore, we need to control for the ruggedness of land and the difficulty of crossing large bodies of water to better identify the effect of imperial capital on today's trade. Geodesic distance may not control for such natural barriers to trade and empire expansion as accurately as a measure taking into account the ease of human movement.

To control for these natural barriers to trade and empire expansion, we calculate the number of hours it would take a human to travel an optimal route between two points, $\grave{a}$ 


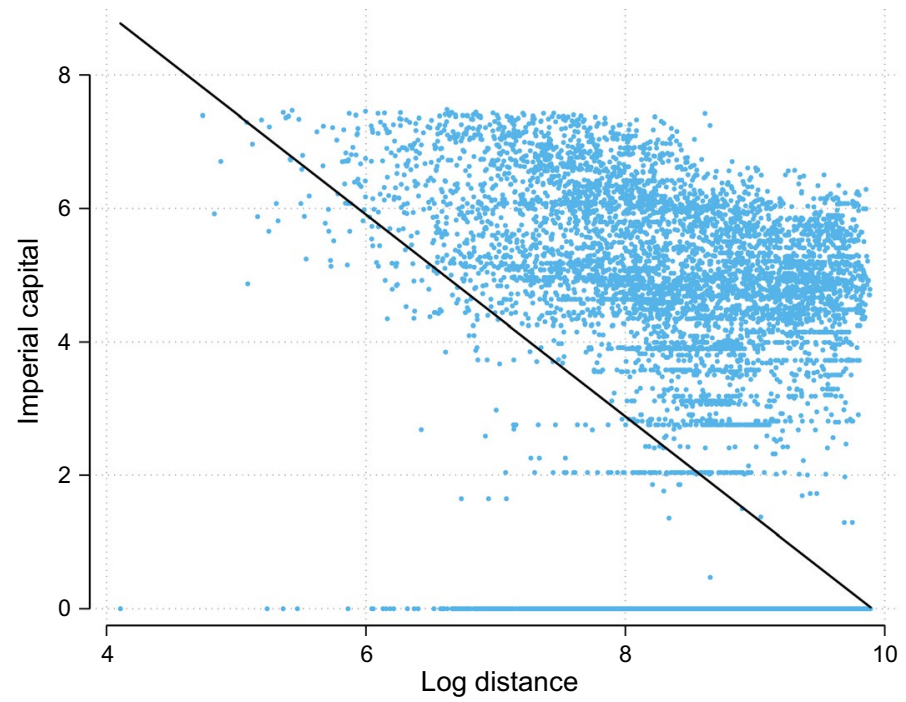

Fig. 3 Imperial capital. Notes This scatter plot correlates imperial capital with geodesic distance and the solid line is a linear fit. Sources: CEPII, and authors' empire data

la Ömer Özak’s Human Migration Index (Özak 2010). ${ }^{19}$ Optimal routes are the quickest, where time required is ruled by a version of the so-called Naismith's rule of walking time required with sloping paths. The rule takes into account that individuals walk slower the steeper the slope, which holds for both ascent and descent, but is asymmetric at 5 degrees angle (walking down at 5 degrees slope is faster than zero degrees, but walking up is slower). When a slope is steeper than 12 degrees, a walker typically will take a detour and find a more lengthy route. ${ }^{20}$

To cross small water bodies, such as rivers, we add additional $3 \mathrm{~h}$. For ocean crossings, we follow Pascali (2017) and take into account wind speed and direction. Global ocean wind speeds come from NASA (2012). We take the average speed and direction for the months of May to August for the years 1999-2009. The speed of a vessel given wind speed and direction of travel is that of a clipper as documented in Pascali (2017) (see Fig. 10 in "Appendix 2" for an illustration of wind speed and directions). We add $24 \mathrm{~h}$ (three days based on $8 \mathrm{~h}$ of walking per day) for boarding and unloading. In our benchmark version, seafaring is limited to $200 \mathrm{~km}$ within coasts (so crossings from Europe over the Atlantic Ocean were not possible before the end of the Middle Ages). The idea is to create a

19 Another project that models ancient travel times is the Stanford Geospatial Network Model of the Roman World. For our project, we required a global scope, and therefore, devised our own network.

20 The precise cost function (in hours) is:

$$
\operatorname{cost}(\text { angle })=\text { distance } / \text { speed }=(\text { height } / \sin (\text { angle })) /\left(1000 * 6 * e^{(-3.5 * \mid \tan (\text { angle })+0.05 \mid)}\right) .
$$

When a slope exceeds 12 degrees, the distance is extended such that we reach the same height but over a longer path at a 12 degrees angle. So, at a flat surface walking speed is $5 \mathrm{~km} / \mathrm{h}$, at 5 degrees descent it is $6 \mathrm{~km} / \mathrm{h}$, and ascent it is $4.2 \mathrm{~km} / \mathrm{h}$. 
geographic barrier measure that is valid for all the years covered by our data. We then use a second travel time measure where ocean sailing is possible. ${ }^{21}$

Figure 4 illustrates how geography impacts human mobility around the Caspian Sea. The Caspian Sea itself poses a barrier to trekking, however, once at sea, sea travel is faster. Mountains lengthen travel time. For example, the Caucasus had a strong influence in shaping the raids of the Rus in the 10th century (Afandiyeva 2018) and still influence the location of oil and gas pipelines in the 20th century around the Caspian Sea. More generally, Fig. 9 in "Appendix 2" gives an overview of the optimal route network we estimate for the entire world.

In our empirical analysis, we use both geodesic distance, to stay in line with the standard gravity model, and our measure of human migration hours, to adapt the gravity equation to our empire-history setting. We also build additional variables that capture trek obstacles (as the ratio of human mobility on land over geodesic distance), or trek obstacles and bad winds (as the human mobility including seafaring divided by geodesic distance). In "Appendix 2", we provide further statistical details on the human mobility measures as well as their correlation with geodesic distance. By and large, the correlation is high, but it varies over distances.

While we assume that a rugged path between countries inhibited their trade and hampered the expansion of empires, it does not necessarily imply that ruggedness itself or geographic obstacles was bad for empires. Indeed, the presence of mountains along many coastlines around the Mediterranean provided easier defense against invaders, as well as natural harbours, forest resources, and a better climate. ${ }^{22}$

\footnotetext{
${ }^{21}$ To implement the above measures, we create a grid of nodes at the global level, one for land and one for water. The distance between all nearest nodes are calculated using a projection-free method in order to avoid distance distortion from any particular projection at the global level. Information on elevation, from which we can derive angles between any two points, are obtained from a global digital elevation map. The grid of nodes has an average distance of around $5 \mathrm{~km}$ on land and $50 \mathrm{~km}$ on seas. At a global level this results in millions of nodes. In order to reduce the number of potential routes between any two countries, we first calculate the optimal route between the nearest (current day) major cities. The distance between two countries is the average distance between all pairs of cities from these two countries. Calculations are executed in PostGIS, code and results will be available on the authors' websites.

${ }^{22}$ Understanding what causes the rise of empires in the first place, and the role of geography in this process, is a weighty question beyond the scope of this paper. Economics literature does not provide a workhorse theory of empire formation. It does provide some insights based on papers on the optimal size of nations and the location of borders. For example, Alesina et al. (2000) suggest that country size in equilibrium might be the result of a tradeoff between lower trade costs and cultural heterogeneity. The idea that enhancing trade is behind the formation of empires is clearly present in this literature. Huning and Wahl (2016) suggest that within the Holy Roman Empire states with a geography more favorable for taxation were financially more stable, geographically larger, and survived longer. This is in line with geography affecting the incentives for a larger empire and a larger tax base. A recent attempt to provide a theory of empire formation is by Peter Turchin. In Turchin et al. (2006), he confirms that we know little on the preconditions for the rise of large empires. He then suggests that across 62 mega empires in history, there is a statically significant tendency for empires to expand more along the east-west axis than north-south. Turchin (2009) notes that location near a steppe frontier correlates with the frequency of empire formation. This is because antagonistic interactions between nomadic pastoralists and settled agriculturalists may pressure both group to scale up polity size, and thus military power. Empire formation can also be seen though the lens of state capacity and what social scientists in general know about the role of agriculture in its origins. A recurring hypothesis is indeed that the surplus generated by a productive and varied agriculture allowed for the emergence of state institutions (see Mayshar et al. 2016, for a discussion of this hypothesis). It is hence likely that geographic variables might have played heterogeneous roles across empires and in the way they affected trade. What we have found in the data is that trek obstacles, as captured by the human walking hours to distance ratio, are negatively correlated with imperial capital, as they are with trade. We also found that, on average, differences in temperature, precipitation, or suitability for agriculture, are nega-
} 


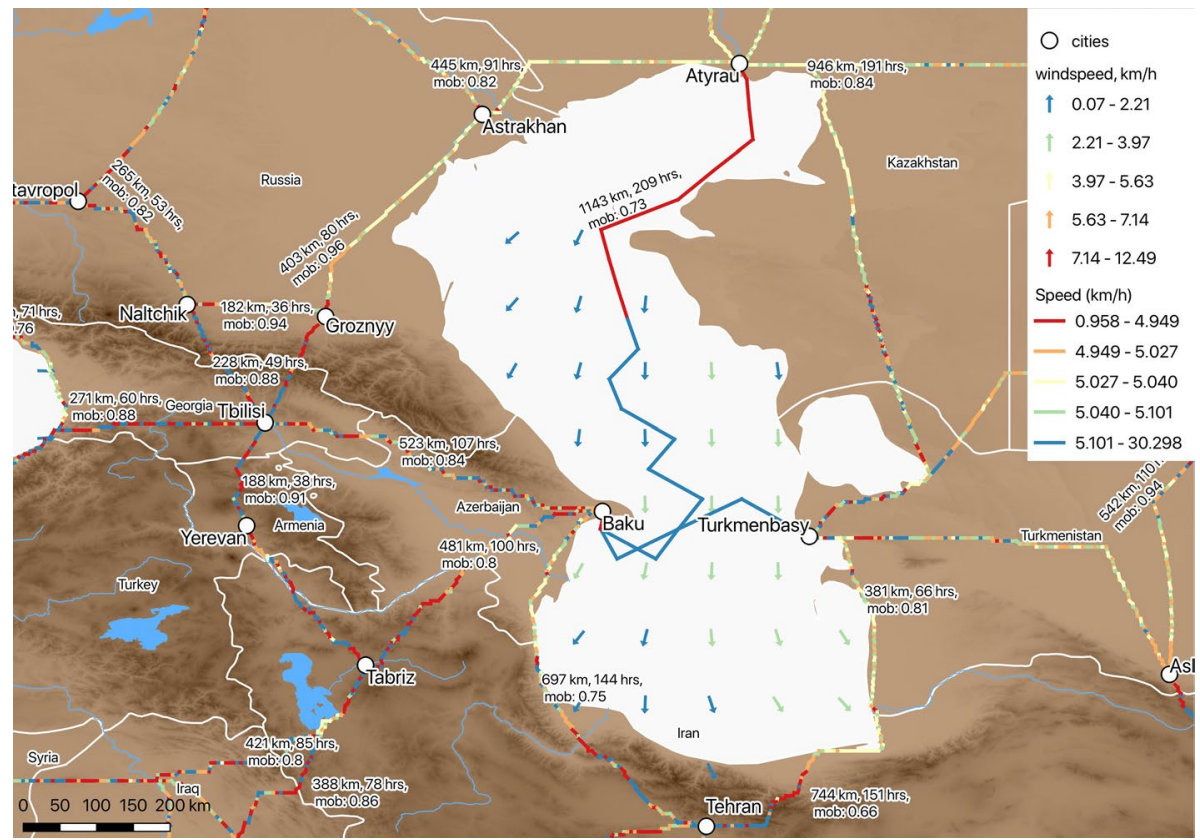

Fig. 4 The optimal route network around the Caspian Sea. Notes The figure represents a part of the global routing map, indicating optimal routes between various cities. The color codings indicate the speed at each section, which depends on altitude difference between the start and the end point of a section. Mountainous areas in the east and the south coincide with increased travel time. Note that the Caspian sea itself is a barrier, as there are limited cities immediately near the sea, and the change of mode (from land to sea voyage) is assumed to be costly. However, sea travel tends to be much faster, and therefore efficient at longer distances. The distance and travel time for each route between two cities is indicated next to each route. Our mobility index (mob) indicates the ratio of travel time of the route to a hypothetical travel time along straight line at a constant speed of $5 \mathrm{~km} / \mathrm{h}$. The figure only includes one way links for clarity, while the underlying data takes into account the variation in slopes going either direction (Color figure online)

\section{Results}

In this section, we bring our newly collected data on empires and our measure of imperial capital to the gravity model.

\subsection{Baseline results}

Table 2 shows our baseline gravity regression results. In these specifications, we only include geographic gravity controls, i.e. geodesic distance, a contiguity dummy, differences in latitudes and longitudes (absolute values), as well as our measures of human mobility, ruggedness and bad winds. All non-dummy control variables are in logs. We keep the

Footnote 22 (continued)

tively correlated with imperial capital as well as with trade today. This goes against that idea that different locations with possible gains from trade from specialization in their comparative advantage would be more likely to form an empire to reduce trade costs. 
baseline specifications parsimonious with controls that are truly exogenous to trade today. We add other determinants of trade, such as common religion, common legal system, or trade agreements, later on when we examine the underlying mechanisms of the imperial capital effect.

Across the board, we find a positive and significant relationship between imperial capital and trade that is robust to various geographic controls. In specifications 3-10, when we control for our measures of geographic barriers, the number of observations is smaller, yet, the results on imperial capital are very similar. ${ }^{23}$ This suggests that natural obstacles to trade and empire expansion do not drive the explanatory power of an imperial past on trade. However, we do find negative and statistically significant effects of bad geography on trade, as expected.

As for the magnitude of the estimates, our lower bound of 0.115 suggests that a $10 \%$ increase in imperial capital is associated with an increase in bilateral trade of around $1.15 \%$, our upper bound suggests a corresponding increase of $1.69 \%$. Doubling imperial capital is associated with a $8.2-12.4 \%$ increase in trade $\left(2^{0.115}\right.$ to $\left.2^{0.169}\right)$. Among countries with at least some imperial capital, moving from a minimal imperial capital to a maximum one brings about a $36 \%$ increase in trade.

Another way to think about this persistence is to consider what happens after a breakup when imperial capital starts depreciating at $0.1 \%$ a year. Forty years after a breakup, imperial capital should decrease by $1-0.999^{40}$, i.e. about $4 \%$. According to our upper bound estimate, this would imply an approximate $0.7 \%$ drop in trade. This is much smaller than what Head et al. (2010) estimate for colonial empires. They find that trade has declined by around $65 \%$ after four decades of independence. We thus estimate a much stronger persistence than what was found for recent colonial empires. We further discuss the difference between colonial and non-colonial imperial capital later in this section. But, first, we assess the robustness of our estimates to alternative specifications and measures of imperial capital.

\subsection{Robustness to alternative measures of imperial capital}

To further assess the robustness of the long-run persistence of empires, we estimate our gravity model using alternative measures of imperial capital. We first use a dummy variable equal to one if the two countries were ever part of the same empire. This dummy captures the existence of a shared imperial past but not the level of imperial capital accumulated between two countries. It lacks the ability to differentiate between long-gone and recent empires but allows for estimating the average legacy of a common imperial history. As other indicators of imperial capital, we also use the number of common empires countries have been part of, as well as the total number of years countries have spent in common empires.

Results using these alternative indicators are in Table 3. Imports from countries that were once in a common empire are on average 55\% larger than from other countries $(\operatorname{asinh}(0.58))$. These results confirm the relevance of past empires in shaping today's trade patterns. The results for the other indicators of imperial capital indicate that $10 \%$ more years of common empire are associated with an increase in trade of around $1.02 \%$, while

\footnotetext{
23 The number of observations is smaller because some country-pairs are separated by more than $200 \mathrm{~km}$ of water and this precludes them to be connected by land human migration. See Fig. 9.
} 


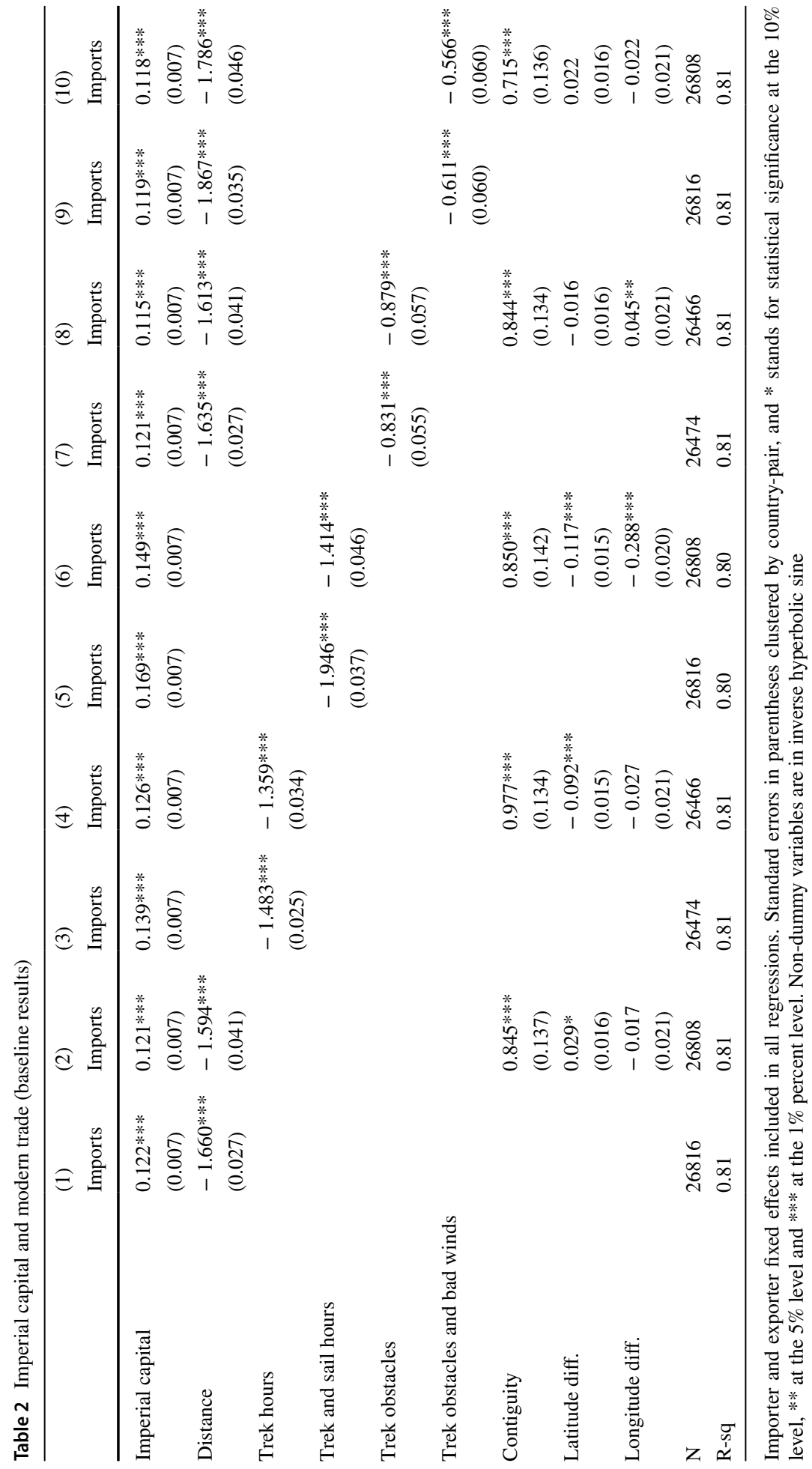




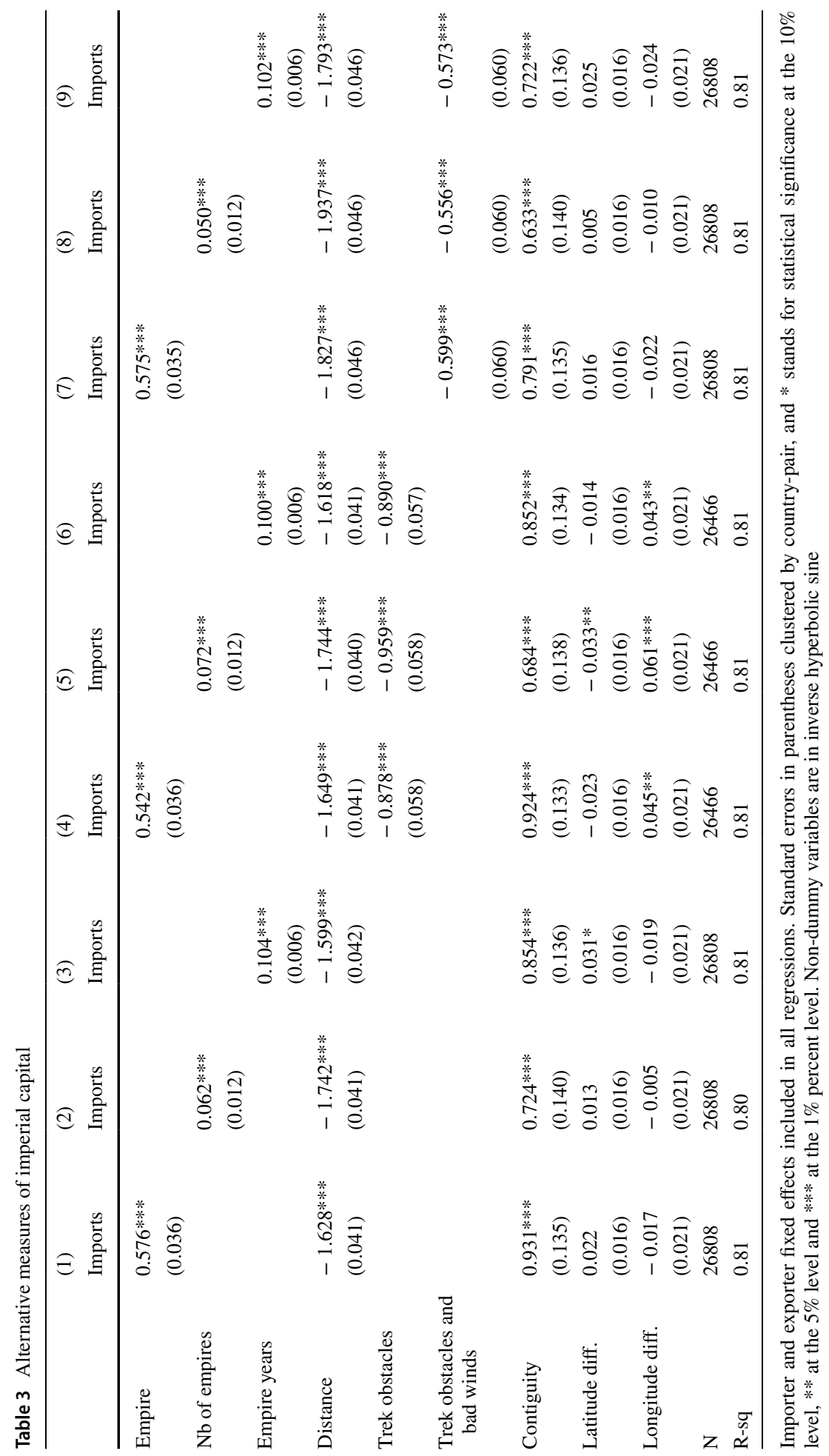


an extra empire is associated with an $6.2 \%$ increase in trade. It is worth noting that none of these indicators take into account both years in and years since past empires, and hence, our preference for our measure of imperial capital.

To verify that the estimated coefficient on a common empire indeed captures a common history and not simply geographic proximity, we run a falsification exercise. To do so, we generate 100 placebo Empire dummy distributions, based on geography, where the probability of two countries being in a joint placebo empire is a function of walking hours on natural optimal routes. More precisely, we generate placebo Empire dummies using a binomial draw, with probability parameter equal to the inverse of the walking hours between countries (multiplied by three so as to match the true share of empires among countrypairs, which is around 30\%). In other words, for each country pair, the placebo Empire dummy is equal to either 1 or 0 , and the probability of that dummy being 1 is determined by geography. Our placebo dummies can thus be seen as a re-shuffling of Empire dummies across country-pairs, but where the shuffles are not completely random. We then estimate the effect of these placebo Empire dummies using the gravity specification of column (1) of Table 3. Figure 5 shows the distribution of the 100 coefficients on placebo Empire dummies. The mean of placebo estimates is centered around zero, and no placebo dummy has a statistically significant relationship with trade. Also, the right tail of the distribution of the estimated placebo effects is nowhere near our lower bound estimate for the Empire coefficient. This exercise assures us that the coefficient on a common imperial past is more than a reflection of geography.

As an extra robustness check, we re-run our baseline specification while including the empire dummy on top of our imperial capital variable. In this specification, the empire dummy accounts for selection into empire, while the parameter on imperial capital captures the intensity of treatment. Results are in Table 4 . We find that, among country-pairs that have shared empires in the past, those that have accumulated more imperial capital trade more today. The results confirm the relevance of our measure of imperial capital in capturing additional information on countries' common history beyond just having been part of the same empires. This result is further illustrated in Fig. 6. It shows how the effect of a common imperial past depends on how much imperial capital has been accumulated, i.e. it depends on how long the periods of common empire lasted, and how many years ago this was. Being in a common empire a long time ago or for a short period of time only increases trade by around 20\%, while it increases it by as much as $75 \%$ if the country pair has accumulated large amounts of imperial capital.

In Tables 5 and 6, we use two alternative measures of imperial capital we described in Sect. 2, namely deep imperial capital and metropole imperial capital. We find deep imperial capital to have a slightly larger coefficient than our baseline measure of imperial capital, confirming the relevance of centralized administrations, religions as well as coin minting in building imperial capital and shaping trade today. When we include both deep imperial capital and our baseline measure in the same regression, we find that it only deep imperial capital that matters. On the other hand, we find that it is not only the relationships with the metropole that contributes to the accumulation of relevant imperial capital. When we include both measures in our regressions, we find that metropole imperial capital has a positive and significant coefficient but about half as large as that of our baseline measure of imperial capital, which takes into account links between all regions of an empire. 


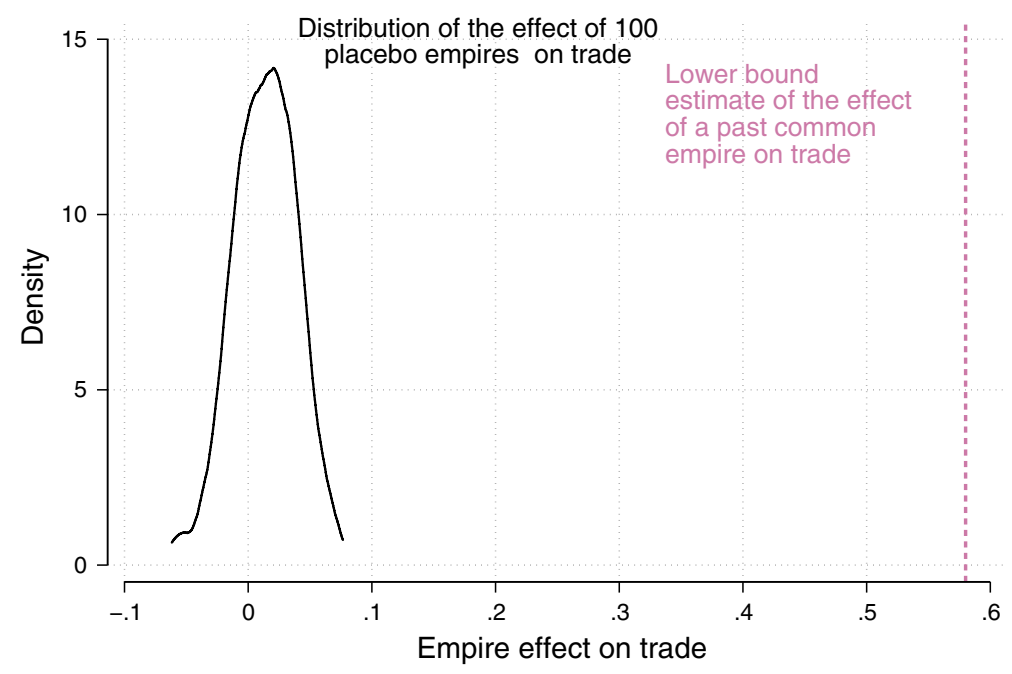

Fig. 5 Placebo estimations. Notes The effects of placebo empires are estimated in a specification akin to that in column (1) of Table 3 . The placebo empires are randomly predicted conditional on human mobility between countries. See text for details

In "Appendix 1", we provide a number of extra robustness checks, such as estimating a non-linear effect of imperial capital on trade, including extra geographic controls such as differences in suitability of agriculture across countries, using a normalized version of imperial capital (normalized as the index of state history in Borcan et al. (2018)), using different rates of depreciation for imperial capital, as well as estimating the effects of imperial capital accumulated during different periods.

\subsection{Observable imperial legacies}

In Table 7, we look at the association of imperial capital with bilateral measures of affinity to explore the potential observable imperial legacies through which imperial capital affects trade today. Such measures of bilateral affinity are often included in gravity models to capture institutional and cultural barriers to trade. However, many of these attributes, e.g. sharing a language, a legal system, or a religion, are a reflection of a shared history that presumably relates to a shared empire. To investigate the relationship between measures of affinity and imperial capital, we employ gravity-type regressions and control for geodesic distance, contiguity, differences in latitudes and longitudes, and trek obstacles (Panel a) or trek obstacles and bad winds (Panel b). Importantly, in columns (1)-(3) of Panels a and b, we confirm that country-pairs with greater accumulated imperial capital are more likely to share a legal system, a language, and a religion. This is in line with the idea that these measures of affinity capture part of the imperial heritage countries share. Our measure of imperial capital is also negatively correlated with linguistic distance, but not significantly with genetic distance. Preferential trade policies might be another mechanism through 


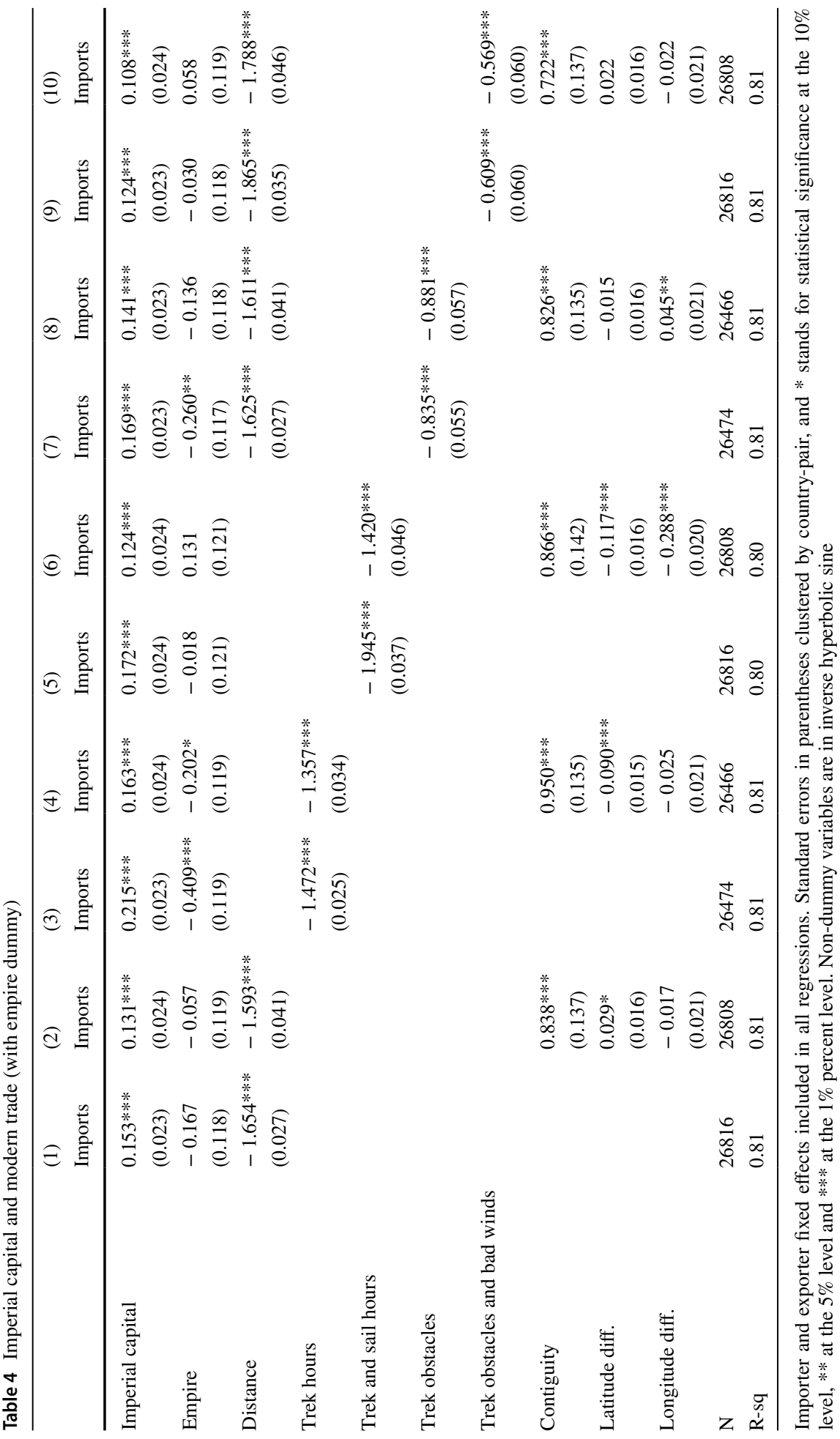


which imperial capital may affect trade. The accumulation of imperial capital could indeed be related to better political relations today, which in turn lead to free trade agreements that boost trade. We find no robust relationship between imperial capital and the probability of a free trade agreement. Hence, it is unlikely that the effect of imperial capital is via current trade policies.

It is clear that a common imperial heritage is part of the reason why countries share institutions and culture, and why this, in turn, has a persistent effect on trade. Nonetheless, the persistent effect of empires on trade is not entirely captured by these gravity variables. Indeed, results in Table 8, using imperial capital, and Table 9, using the empire dummy variable, confirm that the coefficient on imperial capital is still positive and significant when we control for these historical legacies. ${ }^{24}$ The effect of imperial capital is around $50 \%$ smaller when these variables are controlled for (e.g. comparing columns (1) and (2) of Table 8), suggesting that observable historical legacies account for about half of the imperial capital effect. Similarly in Table 9, the difference in imports between empire pairs and non-empire pairs is reduced to $25 \%$, suggesting that around $60 \%$ of the dummy effect is explained by these observables.

To sum up, the legacy of imperial capital partly reflects empires' unifying influence on common languages, religions, or legal systems. These measures of affinity may be the result of past common empires, and may, thus, be viewed as components of imperial capital. At the same time, even though controlling for them does indeed reduce the size of the imperial capital effect, part of the effect still remains unexplained. One possible explanation is that the comparative advantage forces that have shaped empire expansion in the past are still at play today in shaping trade patterns. This would imply that the effect of imperial capital is partly spurious. While we cannot completely rule out this possibility, it would not explain why longer periods of joint empire have a stronger effect on trade, which is in line with our idea of imperial capital as a trade facilitator.

\subsection{Heterogeneity across colonial and non-colonial imperial capital}

We further explore the differential persistence of colonial and non-colonial empires. Colonial empires have been studied previously by both development and trade economists, and the colony dummy is now a staple of gravity equations. It is therefore important to check how our measure of imperial capital differs between colonial and noncolonial empires.

We describe the differences in levels of colonial and non-colonial imperial capital in Table 10. Out of 26,816 country-pairs, 9399 share an imperial past and none of these have seen imperial capital depreciate completely. Out of these 9399 country-pairs, 4743 have colonial capital and 4439 have non-colonial imperial capital (some pairs have both). The level of imperial capital is slightly higher on average when accumulated during non-colonial empires. Among country-pairs with a shared imperial history, the mean of colonial capital is 4.70 , while it is 5.38 for non-colonial imperial capital.

To explore the differential relationships the two types of imperial capital may have with today's trade, we run our gravity regressions including both variables at the same time on the right hand side. Results are in Table 11. We find that both colonial and non-colonial imperial capital have a positive and significant relationship with trade. On

${ }^{24}$ Including genetic and linguistic distances as controls drastically reduces the number of observations. 


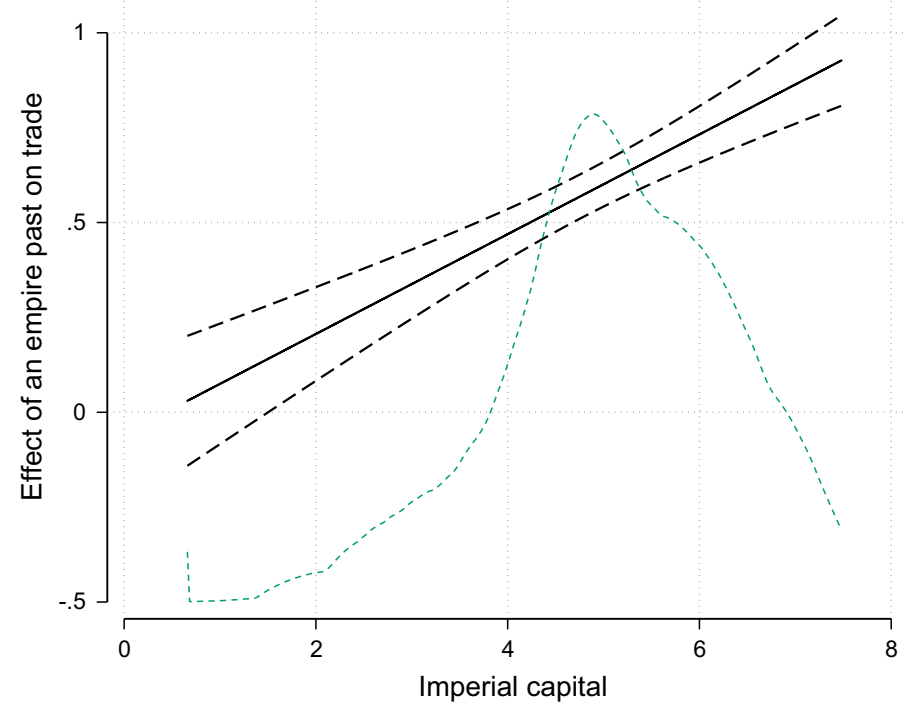

Fig. 6 How the legacy of empires depends on imperial capital. Notes The effect of an empire past is obtained by adding the coefficient on imperial capital multiplied by imperial capital to the coefficient on the empire dummy. The estimates are from column (2) of Table 4. The dashed lines give the $90 \%$ CI and the inverted-u dash line gives the distribution of imperial capital, among pairs that share an empire past

average, the effect of one standard deviation increase in colonial capital is about twice as large as that of non-colonial capital. Colonial empires clearly matter for today's trade, but long-gone non-colonial empires matter as well. This also assures us that our results are not driven merely by colonial empires. To additionally confirm that colonial empires do not drive our results, we run further regressions excluding all country-pairs with positive colonial imperial capital. Results in Table 12 confirm that, among country-pairs that were never part of joint colonial empires, imperial capital accumulated during longgone empires still has a positive effect on trade.

\section{Conclusion}

In Power and Plenty, Findlay and O'Rourke (2009) suggest that "contemporary globalization, and its economic and political consequences, have not arisen out of a vacuum, but from a worldwide process of uneven economic development that has been centuries, if not millennia, in the making." In this paper, we show empirically that there is indeed a persistent legacy of long-gone historical empires affecting a crucial element of globalization, international trade. Imports from countries that were once in a common empire are on average 55\% larger. Hence, the historical legacy of empires clearly left its mark on today's trade patterns. We look into the dynamics of persistence by building a measure of imperial capital that buildups in times of common empire and depreciates over time. Its slow 


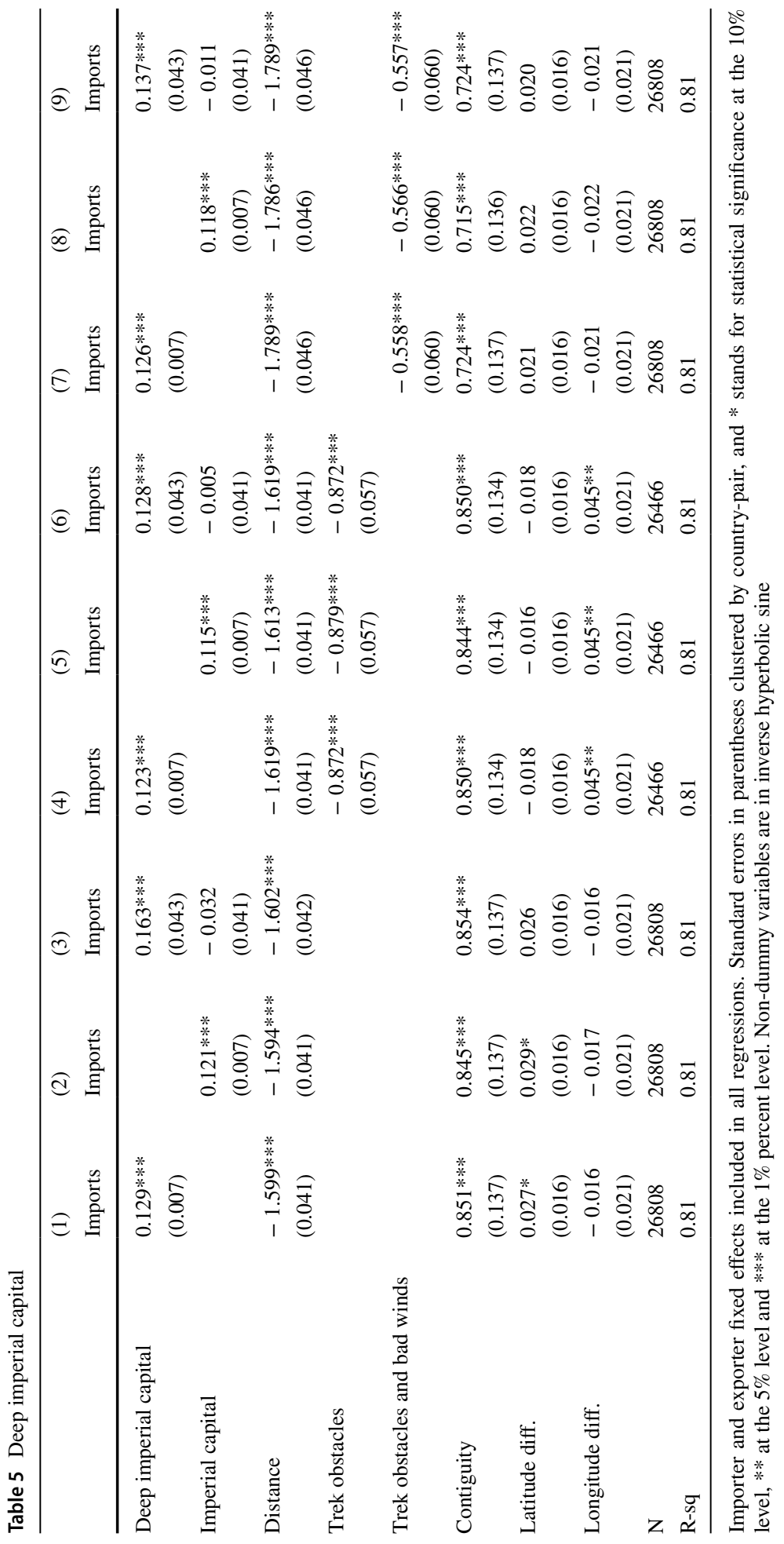




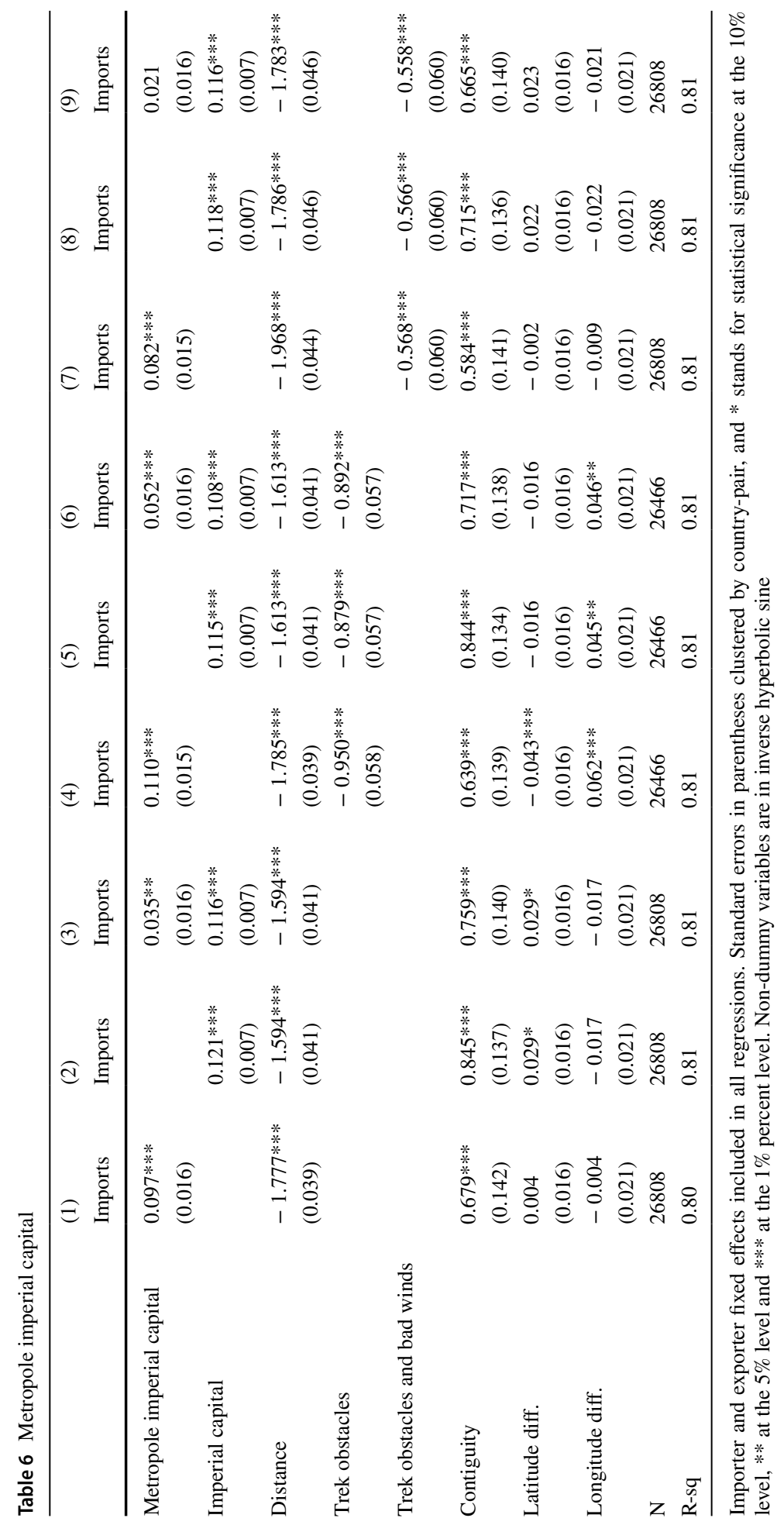




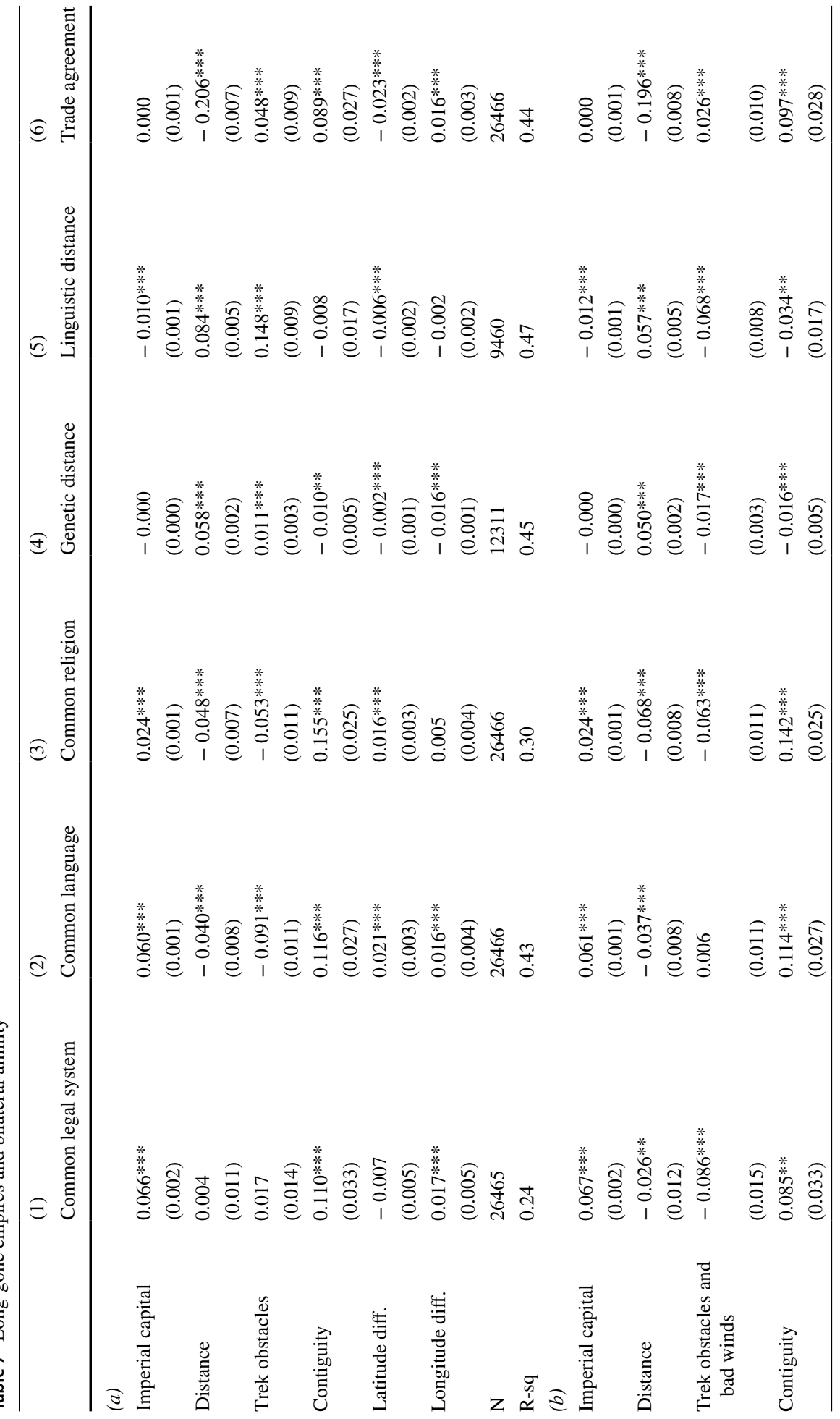




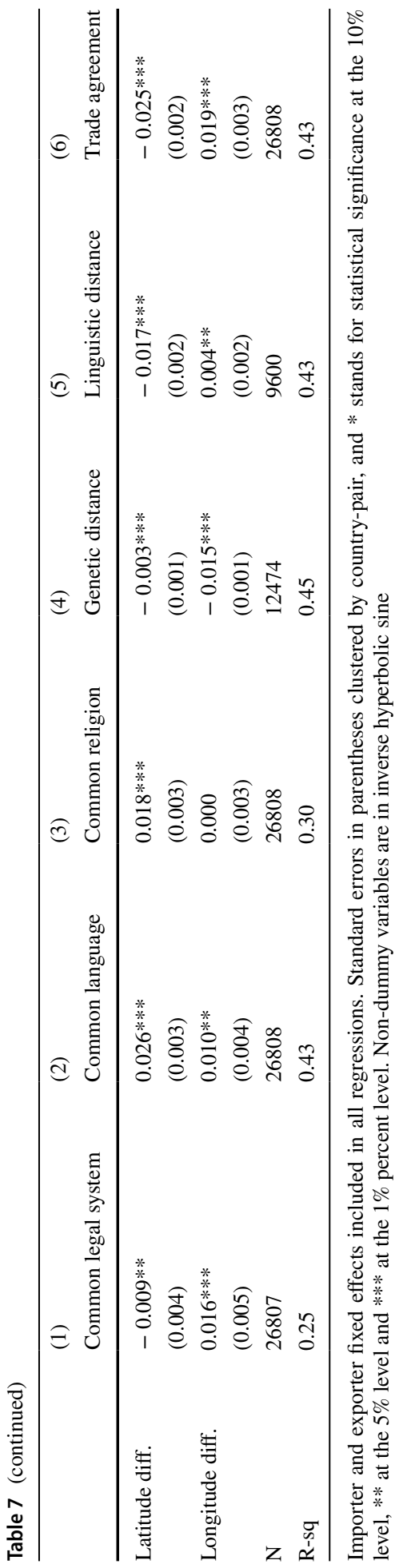




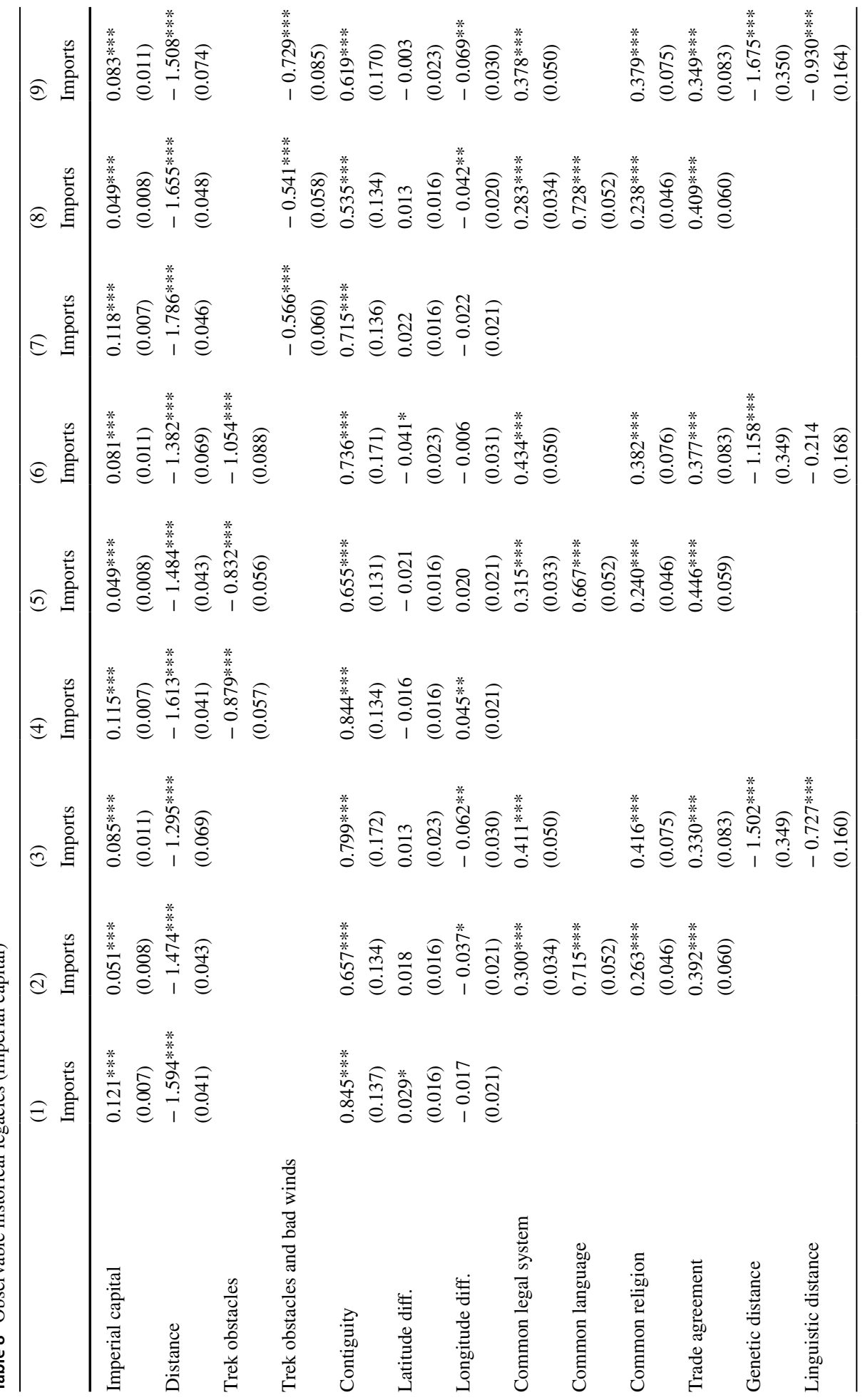




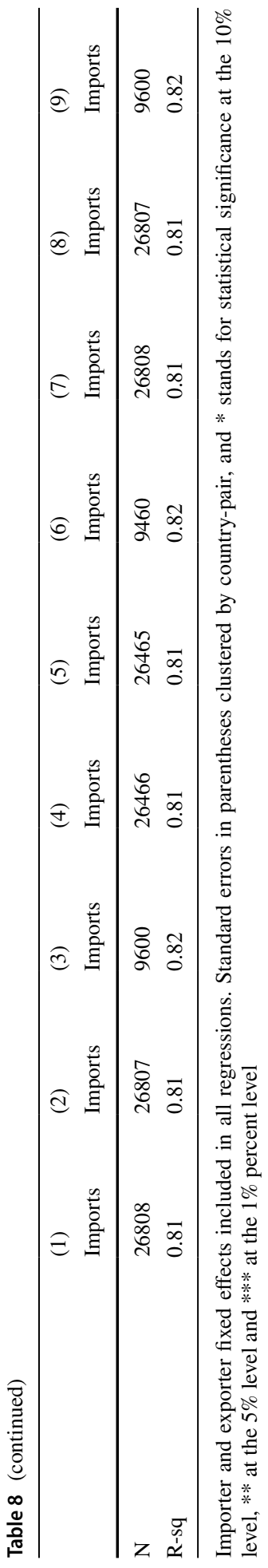




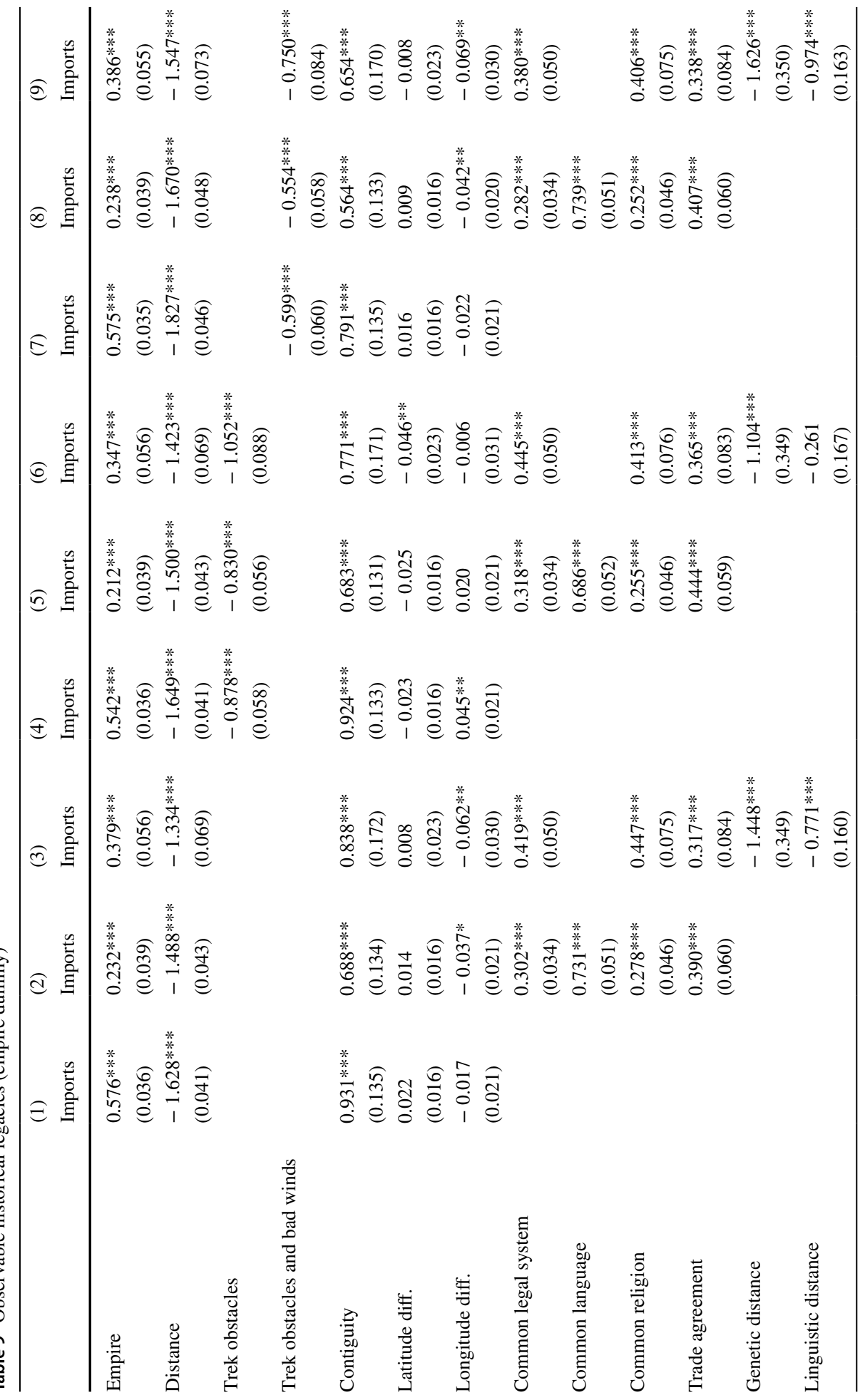




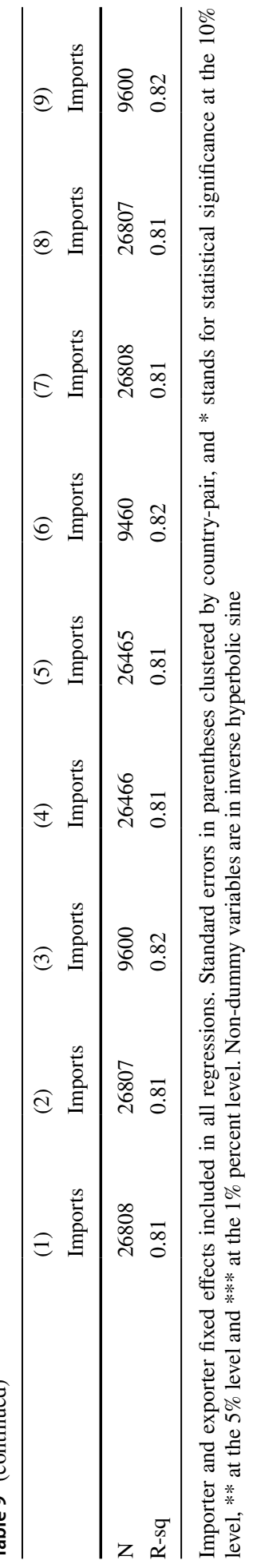


Table 10 Colonial versus noncolonial imperial capital

\begin{tabular}{lccccc}
\hline & Obs. & Mean & SD & Min & Max \\
\hline All observations & & & & & \\
Empire & 26,816 & 0.35 & 0.48 & 0.00 & 1.00 \\
Imperial capital & 26,816 & 1.80 & 2.54 & 0.00 & 7.48 \\
Non-colonial imperial capital & 26,816 & 0.89 & 2.08 & 0.00 & 7.48 \\
Colonial imperial capital & 26,816 & 0.83 & 1.84 & 0.00 & 6.57 \\
Only positive observations & & & & & \\
Empire & 9399 & 1.00 & 0.00 & 1.00 & 1.00 \\
Imperial capital & 9399 & 5.12 & 1.18 & 0.47 & 7.48 \\
Non-colonial imperial capital & 4439 & 5.38 & 1.42 & 0.46 & 7.48 \\
Colonial imperial capital & 4743 & 4.70 & 1.02 & 0.60 & 6.57 \\
\hline
\end{tabular}

Table 11 Colonial and non-colonial imperial capital and modern trade

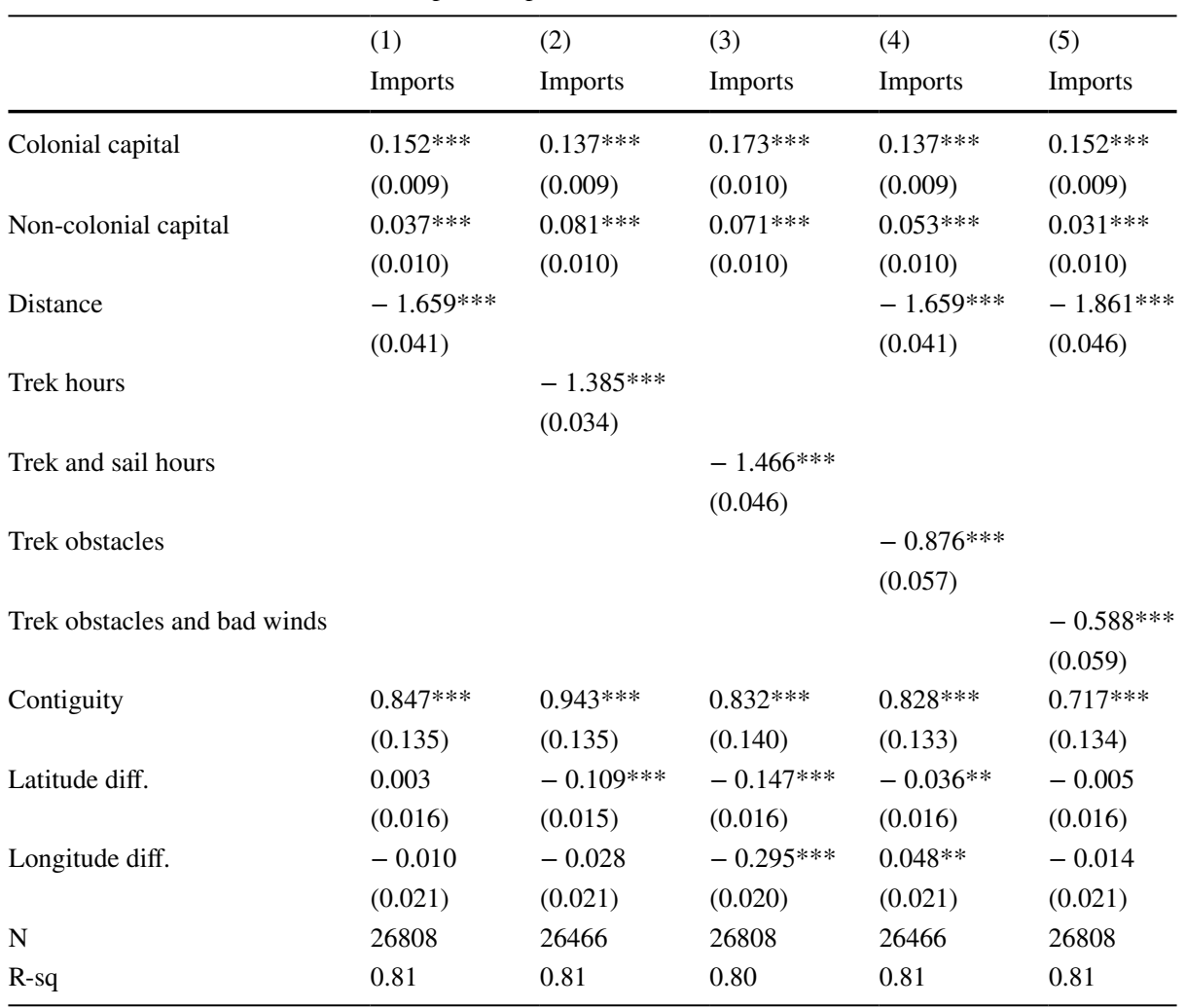

Importer and exporter fixed effects included in all regressions. Standard errors in parenthesis clustered by country-pair, and * stands for statistical significance at the $10 \%$ level, ** at the $5 \%$ level and *** at the $1 \%$ percent level. Non-dummy variables are in inverse hyperbolic sine 
Table 12 Omitting pairs with colonial imperial capital

\begin{tabular}{|c|c|c|c|c|c|}
\hline & (1) & (2) & (3) & (4) & (5) \\
\hline & Imports & Imports & Imports & Imports & Imports \\
\hline \multirow[t]{2}{*}{ Imperial capital } & $0.101 * * *$ & $0.116^{* * *}$ & $0.119 * * *$ & $0.102 * * *$ & $0.096 * * *$ \\
\hline & $(0.009)$ & $(0.009)$ & $(0.009)$ & $(0.009)$ & $(0.009)$ \\
\hline \multirow[t]{2}{*}{ Distance } & $-1.422 * * *$ & & & $-1.464 * * *$ & $-1.664 * * *$ \\
\hline & $(0.048)$ & & & $(0.048)$ & $(0.053)$ \\
\hline \multirow[t]{2}{*}{ Trek hours } & & $-1.245^{* * *}$ & & & \\
\hline & & $(0.041)$ & & & \\
\hline \multirow[t]{2}{*}{ Trek and sail hours } & & & $-1.408 * * *$ & & \\
\hline & & & $(0.051)$ & & \\
\hline \multirow[t]{2}{*}{ Trek obstacles } & & & & $-0.804 * * *$ & \\
\hline & & & & $(0.066)$ & \\
\hline \multirow[t]{2}{*}{ Trek obstacles and bad winds } & & & & & $-0.788 * * *$ \\
\hline & & & & & $(0.068)$ \\
\hline \multirow[t]{2}{*}{ Contiguity } & $0.918 * * *$ & $1.009 * * *$ & $0.787 * * *$ & $0.897 * * *$ & $0.723 * * *$ \\
\hline & $(0.179)$ & $(0.177)$ & $(0.178)$ & $(0.176)$ & $(0.177)$ \\
\hline \multirow[t]{2}{*}{ Latitude diff. } & 0.020 & $-0.085^{* * *}$ & $-0.095 * * *$ & -0.020 & 0.002 \\
\hline & $(0.018)$ & $(0.017)$ & $(0.017)$ & $(0.018)$ & $(0.018)$ \\
\hline \multirow[t]{2}{*}{ Longitude diff. } & -0.030 & $-0.051 * *$ & $-0.184 * * *$ & 0.012 & -0.027 \\
\hline & $(0.023)$ & $(0.023)$ & $(0.022)$ & $(0.024)$ & $(0.023)$ \\
\hline $\mathrm{N}$ & 22067 & 21845 & 22067 & 21845 & 22067 \\
\hline R-sq & 0.81 & 0.81 & 0.81 & 0.81 & 0.81 \\
\hline
\end{tabular}

Importer and exporter fixed effects included in all regressions. Standard errors in parenthesis clustered by country-pair, and $*$ stands for statistical significance at the $10 \%$ level, $* *$ at the $5 \%$ level and $* * *$ at the $1 \%$ percent level. Non-dummy variables are in inverse hyperbolic sine

erosion explains the persistence of long-gone empires. Imperial capital influences trade beyond imperial legacies such as common languages, religions, legal systems, and importantly, beyond the ease of natural trade and invasion routes. This suggests a persistent and previously unexplored effect of long-gone empires on trade. Our paper thus contributes to an emerging literature on long-run legacies by looking at the case of empires and persistent trade patterns. While we only looked at trade patterns in this paper, Fig. 7 suggests that countries which have shared empires with many countries over many years are richer today. This makes for promising future research, especially given previous research suggesting a positive effect of isolation on innovation and prosperity (Ashraf et al. 2010; Özak 2018). 


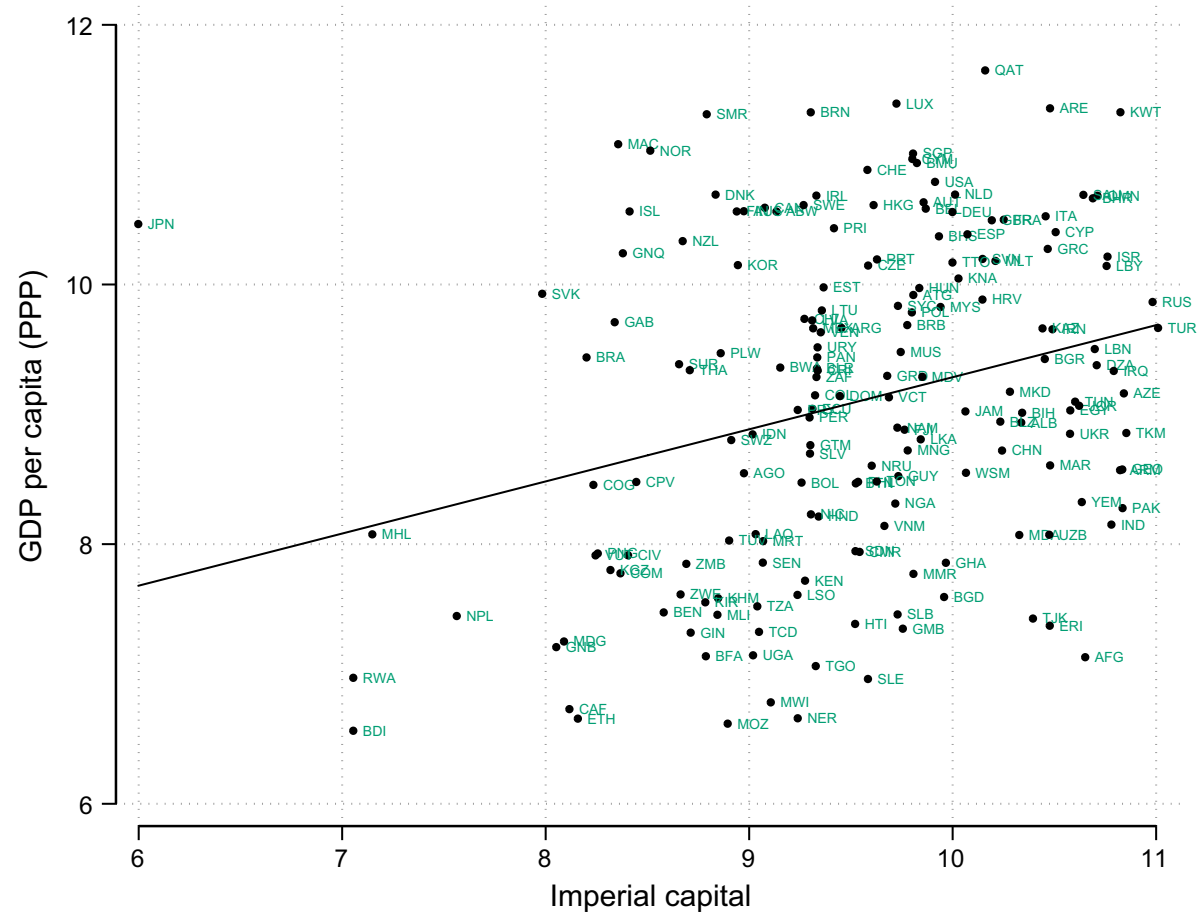

Fig. 7 Imperial capital and GDP per capita today. Notes This graph shows the correlation between GDP per capita and imperial capital. GDP per capita is in Purchasing Power Parity and is from the World Development Indicators. We take the average of available years in the $2000 \mathrm{~s}$

Acknowledgements We are grateful to three anonymous referees, Roberto Bonfatti, Anton Howes, Saumitra Jha, Vania Licio, Eric Monnet, Nathan Nunn, Shanker Satyanath, Dionysios Stathakopoulos, and seminar participants at the 2016 Canadian Economic Association Annual Meeting in Ottawa, QPE lunch at King's College London, 2017 FREIT Workshop in Cagliari, 2018 Royal Economic Society Annual Conference at Sussex, 2018 Moscow Political Economy and Development Workshop at NES, 2018 ASREC Europe at the University of Luxembourg, the University of Victoria (Canada), IFN Stockholm, and the 2019 ASREC Europe meeting in Lund for constructive comments. We also thank Aleksandra Alferova and Danila Smirnov for excellent research assistance.

Open Access This article is licensed under a Creative Commons Attribution 4.0 International License, which permits use, sharing, adaptation, distribution and reproduction in any medium or format, as long as you give appropriate credit to the original author(s) and the source, provide a link to the Creative Commons licence, and indicate if changes were made. The images or other third party material in this article are included in the article's Creative Commons licence, unless indicated otherwise in a credit line to the material. If material is not included in the article's Creative Commons licence and your intended use is not permitted by statutory regulation or exceeds the permitted use, you will need to obtain permission directly from the copyright holder. To view a copy of this licence, visit http://creativecommons.org/licenses/by/4.0/.

\section{Appendix 1: Extra robustness checks}

In this section, we provide a number of extra robustness checks. 


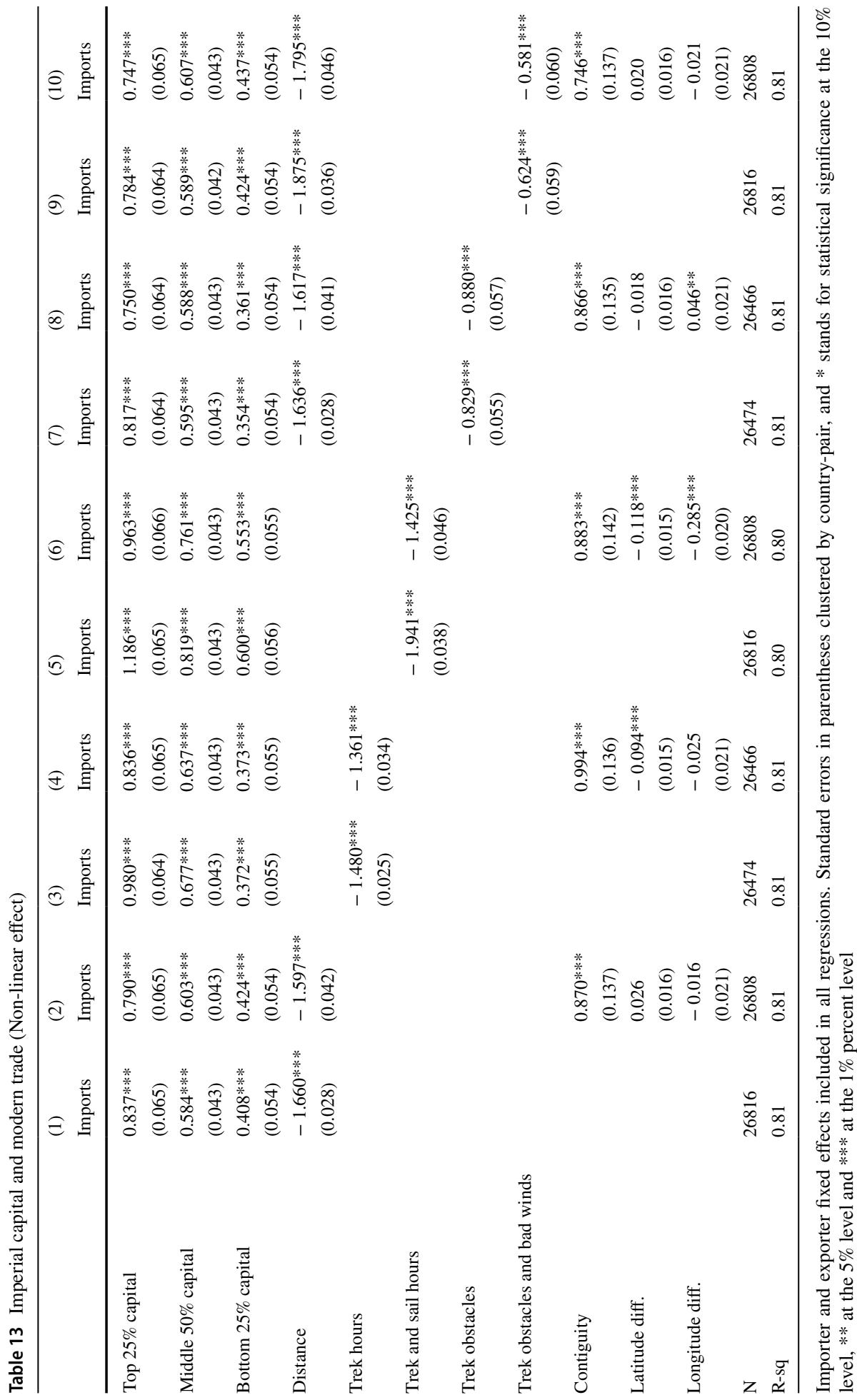


Table 14 Imperial capital and modern trade (Extra geographic controls)

\begin{tabular}{|c|c|c|c|c|c|}
\hline & $\begin{array}{l}\text { (1) } \\
\text { Imports }\end{array}$ & $\begin{array}{l}(2) \\
\text { Imports }\end{array}$ & $\begin{array}{l}(3) \\
\text { Imports }\end{array}$ & $\begin{array}{l}\text { (4) } \\
\text { Imports }\end{array}$ & $\begin{array}{l}\text { (5) } \\
\text { Imports }\end{array}$ \\
\hline Imperial capital & $\begin{array}{l}0.126 * * * \\
(0.009)\end{array}$ & $\begin{array}{l}0.122 * * * \\
(0.009)\end{array}$ & $\begin{array}{l}0.147 * * * \\
(0.009)\end{array}$ & $\begin{array}{l}0.116^{* * * *} \\
(0.009)\end{array}$ & $\begin{array}{l}0.121 * * * \\
(0.009)\end{array}$ \\
\hline Distance & $\begin{array}{l}-1.434 * * * \\
(0.051)\end{array}$ & & & $\begin{array}{l}-1.473^{* * *} \\
(0.050)\end{array}$ & $\begin{array}{l}-1.681 * * * \\
(0.057)\end{array}$ \\
\hline Trek hours & & $\begin{array}{l}-1.321 * * * \\
(0.043)\end{array}$ & & & \\
\hline Trek and sail hours & & & $\begin{array}{l}-1.400 * * * \\
(0.056)\end{array}$ & & \\
\hline Trek obstacles & & & & $\begin{array}{l}-0.992^{* * *} \\
(0.071)\end{array}$ & \\
\hline Trek obstacles and bad winds & & & & & $\begin{array}{l}-0.744 * * * \\
(0.072)\end{array}$ \\
\hline Contiguity & $\begin{array}{l}1.087 * * * \\
(0.144)\end{array}$ & $\begin{array}{l}1.080 * * * \\
(0.142)\end{array}$ & $\begin{array}{l}1.029 * * * \\
(0.148)\end{array}$ & $\begin{array}{l}1.013 * * * \\
(0.142)\end{array}$ & $\begin{array}{l}0.913 * * * \\
(0.144)\end{array}$ \\
\hline Latitude diff. & $\begin{array}{l}0.071 * * * \\
(0.023)\end{array}$ & $\begin{array}{l}-0.026 \\
(0.022)\end{array}$ & $\begin{array}{l}-0.038^{*} \\
(0.023)\end{array}$ & $\begin{array}{l}0.018 \\
(0.023)\end{array}$ & $\begin{array}{l}0.059 * * \\
(0.023)\end{array}$ \\
\hline Longitude diff. & $\begin{array}{l}-0.027 \\
(0.025)\end{array}$ & $\begin{array}{l}-0.018 \\
(0.024)\end{array}$ & $\begin{array}{l}-0.202^{* * * *} \\
(0.023)\end{array}$ & $\begin{array}{l}0.023 \\
(0.025)\end{array}$ & $\begin{array}{l}-0.029 \\
(0.025)\end{array}$ \\
\hline Temperature diff. & $\begin{array}{l}-0.010^{* * * *} \\
(0.003)\end{array}$ & $\begin{array}{l}-0.014 * * * \\
(0.003)\end{array}$ & $\begin{array}{l}-0.012^{* * *} \\
(0.003)\end{array}$ & $\begin{array}{l}-0.012 * * * \\
(0.003)\end{array}$ & $\begin{array}{l}-0.009 * * * \\
(0.003)\end{array}$ \\
\hline Precipitation diff. & $\begin{array}{l}-0.002 \\
(0.005)\end{array}$ & $\begin{array}{l}0.003 \\
(0.005)\end{array}$ & $\begin{array}{l}-0.013^{* * *} \\
(0.005)\end{array}$ & $\begin{array}{l}0.002 \\
(0.005)\end{array}$ & $\begin{array}{l}-0.008 \\
(0.005)\end{array}$ \\
\hline Agro-suitability diff. & $\begin{array}{l}-0.212^{* *} \\
(0.094)\end{array}$ & $\begin{array}{l}-0.197 * * \\
(0.094)\end{array}$ & $\begin{array}{l}-0.128 \\
(0.094)\end{array}$ & $\begin{array}{l}-0.200^{* * *} \\
(0.094)\end{array}$ & $\begin{array}{l}-0.163 * \\
(0.093)\end{array}$ \\
\hline $\mathrm{N}$ & 18878 & 18597 & 18878 & 18597 & 18878 \\
\hline R-sq & 0.81 & 0.81 & 0.81 & 0.81 & 0.81 \\
\hline
\end{tabular}

Importer and exporter fixed effects included in all regressions. Standard errors in parentheses clustered by country-pair, and * stands for statistical significance at the $10 \%$ level, ** at the $5 \%$ level and *** at the $1 \%$ percent level

In Table 13, we estimate non-linear effects of imperial capital on trade. Instead of including our continuous measure of imperial capital, we use dummies that capture weather the country pair is within the top $25 \%$ among pairs with imperial capital, or among the bottom $25 \%$, or in the middle $50 \%$. The reference group is country-pairs with no imperial capital. We find positive and significant effects for these three dummies. The effect of being in the bottom $25 \%$ of imperial capital is, across specifications, smaller than the effect of being in the top $25 \%$ or the middle $50 \%$. Being in the top $25 \%$ seems to have the biggest effect on trade. The magnitude of the coefficients confirm the relevance of measuring the intensity of common imperial pasts.

In Table 14, we check how robust our results are to extra geographic controls such as differences in temperature, precipitation, and suitability of agriculture across countries. While the number of observations goes down due to data availability, our coefficients on 
Table 15 Imperial capital and modern trade (by Rauch's trade classification)

\begin{tabular}{|c|c|c|c|c|c|c|c|}
\hline & (1) & (2) & (3) & (4) & (5) & (6) & (7) \\
\hline & Differentiated & Listed & Homgenous & Listed & Differentiated & Homgenous & Rauch total \\
\hline \multirow{2}{*}{$\begin{array}{r}\text { Imperial } \\
\text { capital }\end{array}$} & $0.107 * * *$ & $0.110 * * *$ & $0.132 * * *$ & $0.108 * * *$ & $0.106^{* * *}$ & $0.130 * * *$ & $0.109^{* * *}$ \\
\hline & $(0.006)$ & $(0.008)$ & $(0.009)$ & $(0.008)$ & $(0.006)$ & $(0.009)$ & $(0.007)$ \\
\hline Distance & $\begin{array}{l}-1.446 * * * \\
(0.037)\end{array}$ & $\begin{array}{l}-1.489^{* * *} \\
(0.045)\end{array}$ & $\begin{array}{l}-1.225^{* * *} \\
(0.054)\end{array}$ & $\begin{array}{l}-1.709 * * * \\
(0.049)\end{array}$ & $\begin{array}{l}-1.499 * * * \\
(0.041)\end{array}$ & $\begin{array}{l}-1.458^{* * *} \\
(0.059)\end{array}$ & $\begin{array}{l}-1.551^{\text {*** }} \\
(0.043)\end{array}$ \\
\hline \multirow[t]{2}{*}{$\begin{array}{l}\text { Trek } \\
\text { obsta- } \\
\text { cles } \\
\text { and bad } \\
\text { winds }\end{array}$} & & & & $-0.644 * * *$ & $-0.155^{* * *}$ & $-0.679 * * *$ & $-0.481 * * *$ \\
\hline & & & & $(0.061)$ & $(0.052)$ & $(0.073)$ & $(0.055)$ \\
\hline \multirow{2}{*}{$\begin{array}{l}\text { Contigu- } \\
\text { ity }\end{array}$} & $1.135 * * *$ & $1.358^{* * *}$ & $1.443^{* * *}$ & $1.202 * * *$ & $1.098 * * *$ & $1.279 * * *$ & $0.960 * * *$ \\
\hline & $(0.120)$ & $(0.129)$ & $(0.133)$ & $(0.128)$ & $(0.120)$ & $(0.134)$ & $(0.121)$ \\
\hline \multirow{2}{*}{$\begin{array}{l}\text { Latitude } \\
\text { diff. }\end{array}$} & $-0.049 * * *$ & -0.001 & $-0.040^{*}$ & -0.006 & $-0.050 * * *$ & $-0.046 * *$ & -0.014 \\
\hline & $(0.015)$ & $(0.018)$ & $(0.021)$ & $(0.018)$ & $(0.015)$ & $(0.021)$ & $(0.015)$ \\
\hline \multirow{2}{*}{$\begin{array}{c}\text { Longi- } \\
\text { tude } \\
\text { diff. }\end{array}$} & $0.048 * *$ & 0.010 & -0.044 & 0.005 & $0.047 * *$ & $-0.050 *$ & 0.014 \\
\hline & $(0.019)$ & $(0.023)$ & $(0.029)$ & $(0.023)$ & $(0.019)$ & $(0.029)$ & $(0.020)$ \\
\hline $\mathrm{N}$ & 21614 & 21614 & 21614 & 21614 & 21614 & 21614 & 21614 \\
\hline R-sq & 0.84 & 0.76 & 0.67 & 0.77 & 0.84 & 0.67 & 0.82 \\
\hline
\end{tabular}

Importer and exporter fixed effects included in all regressions. Standard errors in parentheses clustered by country-pair, and * stands for statistical significance at the $10 \%$ level, ** at the $5 \%$ level and *** at the $1 \%$ percent level

imperial capital are not affected. We find that differences in temperature and agro-suitability reduce trade, which goes against the idea that countries with more pronounced differences in comparative advantage would trade more.

In Table 15, we disaggregate trade along Rauch (1999)'s classification of products into homogenous, listed (or reference-priced), and differentiated products. The data here is from Melitz and Toubal (2014). Rauch (1999) show that proximity, common language, and colonial ties matter more for trade in differentiated products as search and contract-enforcement costs are larger for this type of trade. Here our aim is to check if imperial capital is also mostly associated with trade in differentiated products. We find no large differences in coefficients across product categories. Imperial capital is slightly more correlated with trade in homogenous goods.

In Table 16, we use a normalized version of imperial capital, normalized in the same way as the index of state history in Borcan et al. (2018), where the maximum imperial capital is 1 . The coefficients here can hence be interpreted as the effect of going from no imperial capital to the maximum level. Our lower bound results suggest that this increase in imperial capital more than doubles trade.

In Table 17, we check how sensitive our results are to the rate of depreciation of imperial capital. In our baseline, we followed Borcan et al. (2018) and assumed a decay rate of $0.1 \%$ per year, but it is possible that imperial capital depreciates much slower, or much faster. 
Table 16 Imperial capital and modern trade (Normalized index)

\begin{tabular}{|c|c|c|c|c|c|}
\hline & (1) & (2) & (3) & (4) & (5) \\
\hline & Imports & Imports & Imports & Imports & Imports \\
\hline Normalized capital & $\begin{array}{l}1.305^{* * * *} \\
(0.183)\end{array}$ & $\begin{array}{l}1.607 * * * \\
(0.181)\end{array}$ & $\begin{array}{l}1.449 * * * \\
(0.187)\end{array}$ & $\begin{array}{l}1.342 * * * \\
(0.181)\end{array}$ & $\begin{array}{l}1.108 * * * \\
(0.183)\end{array}$ \\
\hline Distance & $\begin{array}{l}-1.705^{* * *} \\
(0.041)\end{array}$ & & & $\begin{array}{l}-1.713^{* * *} \\
(0.040)\end{array}$ & $\begin{array}{l}-1.898 * * * \\
(0.045)\end{array}$ \\
\hline Trek hours & & $\begin{array}{l}-1.444 * * * \\
(0.034)\end{array}$ & & & \\
\hline Trek and sail hours & & & $\begin{array}{l}-1.503^{* * *} \\
(0.046)\end{array}$ & & \\
\hline Trek obstacles & & & & $\begin{array}{l}-0.932 * * * \\
(0.057)\end{array}$ & \\
\hline Trek obstacles and bad winds & & & & & $\begin{array}{l}-0.539 * * * \\
(0.060)\end{array}$ \\
\hline Contiguity & $\begin{array}{l}0.707 * * * \\
(0.141)\end{array}$ & $\begin{array}{l}0.799 * * * \\
(0.140)\end{array}$ & $\begin{array}{l}0.738 * * * \\
(0.149)\end{array}$ & $\begin{array}{l}0.695 * * * \\
(0.138)\end{array}$ & $\begin{array}{l}0.615^{* * * *} \\
(0.140)\end{array}$ \\
\hline Latitude diff. & $\begin{array}{l}0.014 \\
(0.016)\end{array}$ & $\begin{array}{l}-0.112 * * * \\
(0.015)\end{array}$ & $\begin{array}{l}-0.158^{* * * *} \\
(0.016)\end{array}$ & $\begin{array}{l}-0.032 * * \\
(0.016)\end{array}$ & $\begin{array}{l}0.006 \\
(0.016)\end{array}$ \\
\hline Longitude diff. & $\begin{array}{l}-0.005 \\
(0.021)\end{array}$ & $\begin{array}{l}-0.015 \\
(0.021)\end{array}$ & $\begin{array}{l}-0.311 * * * \\
(0.020)\end{array}$ & $\begin{array}{l}0.060 * * * \\
(0.022)\end{array}$ & $\begin{array}{l}-0.009 \\
(0.021)\end{array}$ \\
\hline $\mathrm{N}$ & 26808 & 26466 & 26808 & 26466 & 26808 \\
\hline R-sq & 0.80 & 0.81 & 0.80 & 0.81 & 0.81 \\
\hline
\end{tabular}

Importer and exporter fixed effects included in all regressions. Standard errors in parentheses clustered by country-pair, and * stands for statistical significance at the $10 \%$ level, ** at the $5 \%$ level and *** at the $1 \%$ percent level

The consequence of different depreciation rates is potentially both in the set of countries pairs that have non-zero imperial capital, and in the distribution of those which have. To investigate how these differences in depreciation rates would affect our results on the effect of imperial capital on trade, we ran our baseline speciation using six other depreciation rates, from $0.01 \%$ a year to $1 \%$ a year. We find a positive and significant effect for all these rates, suggesting the choice of depreciation parameters is not crucial in our specification.

In Table 18, we estimate the effects of imperial capital accumulated during different periods. We find positive effects of imperial capital accumulated during all periods except during 500-1000 AD, possibly reflecting a dark period of imperial history. We also find that capital accumulated during 2000BC to 0AD matters as much as capital accumulated in the last 500 years [columns (2)-(4)].

Finally in Table 19, we focus only on country-pairs that have been in common empires. All these country-pairs have positive imperial capital today. We find a positive and significant coefficient on imperial capital in 9 out of 10 regressions, confirming that the level of imperial capital matters beyond having just some imperial capital.

We also investigate whether all empires have a positive effect on trade. Some empires lasted longer than others, some existed a long time ago, and some were better than others 
Table 17 Imperial capital and modern trade (Sensitivity to decay rates)

\begin{tabular}{|c|c|c|c|c|c|c|c|}
\hline & (1) & (2) & (3) & (4) & (5) & (6) & (7) \\
\hline & Imports & Imports & Imports & Imports & Imports & Imports & Imports \\
\hline Decay .01\% & $\begin{array}{l}0.105 * * * \\
(0.007)\end{array}$ & & & & & & \\
\hline Decay . $02 \%$ & & $\begin{array}{l}0.107 * * * \\
(0.007)\end{array}$ & & & & & \\
\hline Decay $.05 \%$ & & & $\begin{array}{l}0.112 * * * \\
(0.007)\end{array}$ & & & & \\
\hline Decay .10\% & & & & $\begin{array}{l}0.121 * * * \\
(0.007)\end{array}$ & & & \\
\hline Decay . $20 \%$ & & & & & $\begin{array}{l}0.137 * * * \\
(0.008)\end{array}$ & & \\
\hline Decay . $36 \%$ & & & & & & $\begin{array}{l}0.154 * * * \\
(0.008)\end{array}$ & \\
\hline Decay $1.0 \%$ & & & & & & & $\begin{array}{l}0.192 * * * \\
(0.010)\end{array}$ \\
\hline Distance & $\begin{array}{l}-1.599 * * * \\
(0.042)\end{array}$ & $\begin{array}{l}-1.598 * * * \\
(0.042)\end{array}$ & $\begin{array}{l}-1.596^{* * * *} \\
(0.042)\end{array}$ & $\begin{array}{l}-1.594 * * * \\
(0.041)\end{array}$ & $\begin{array}{l}-1.593 * * * \\
(0.041)\end{array}$ & $\begin{array}{l}-1.607^{* * * *} \\
(0.041)\end{array}$ & $\begin{array}{l}-1.642^{* * *} \\
(0.040)\end{array}$ \\
\hline Contiguity & $\begin{array}{l}0.864 * * * \\
(0.136)\end{array}$ & $\begin{array}{l}0.862 * * * \\
(0.136)\end{array}$ & $\begin{array}{l}0.856^{* * * *} \\
(0.136)\end{array}$ & $\begin{array}{l}0.845^{* * * *} \\
(0.137)\end{array}$ & $\begin{array}{l}0.817 * * * \\
(0.137)\end{array}$ & $\begin{array}{l}0.768 * * * \\
(0.137)\end{array}$ & $\begin{array}{l}0.724 * * * \\
(0.137)\end{array}$ \\
\hline $\begin{array}{l}\text { Latitude } \\
\text { diff. }\end{array}$ & $\begin{array}{l}0.031 * \\
(0.016)\end{array}$ & $\begin{array}{l}0.031 * \\
(0.016)\end{array}$ & $\begin{array}{l}0.030 * \\
(0.016)\end{array}$ & $\begin{array}{l}0.029 * \\
(0.016)\end{array}$ & $\begin{array}{l}0.025 \\
(0.016)\end{array}$ & $\begin{array}{l}0.019 \\
(0.016)\end{array}$ & $\begin{array}{l}0.014 \\
(0.016)\end{array}$ \\
\hline $\begin{array}{l}\text { Longitude } \\
\text { diff. }\end{array}$ & $\begin{array}{l}-0.019 \\
(0.021)\end{array}$ & $\begin{array}{l}-0.019 \\
(0.021)\end{array}$ & $\begin{array}{l}-0.018 \\
(0.021)\end{array}$ & $\begin{array}{l}-0.017 \\
(0.021)\end{array}$ & $\begin{array}{l}-0.014 \\
(0.021)\end{array}$ & $\begin{array}{l}-0.008 \\
(0.021)\end{array}$ & $\begin{array}{l}-0.007 \\
(0.021)\end{array}$ \\
\hline $\mathrm{N}$ & 26808 & 26808 & 26808 & 26808 & 26808 & 26808 & 26808 \\
\hline R-sq & 0.81 & 0.81 & 0.81 & 0.81 & 0.81 & 0.81 & 0.81 \\
\hline
\end{tabular}

Importer and exporter fixed effects included in all regressions. Standard errors in parentheses clustered by country-pair, and * stands for statistical significance at the $10 \%$ level, ** at the $5 \%$ level and *** at the $1 \%$ percent level

at building imperial capital. For this additional exercise, we include 168 indicators, one for each empire, to estimate the effect of each empire individually. ${ }^{25}$ Figure 8 presents the 30 most influential empires. Interestingly, the Hotaki Dynasty and Rashidun Capiphate, as well as the Belgian Colonial Empire, have the biggest effects. Other top-30 empires include the Akkadian Empire in the Middle East, the Lozi Empire in Southern Africa, and the Inca Empire in South America. The French and Italian colonial empires are also among the top 30 empire effects. It is important to note that the magnitudes of the empire effects are smaller than that of the general empire dummy. This is because the latter often captures the aggregate effect of many successive empires. Moreover, the counterfactual in this exercise is not country-pairs that have never been in a common empire, but rather countrypairs which have been in different empires at different points in time. This explains why

${ }^{25}$ We are able to estimate 155 coefficients due to collinearity. 
Table 18 Imperial capital and modern trade (Imperial capital at different times)

\begin{tabular}{|c|c|c|c|c|c|}
\hline & (1) & (2) & (3) & (4) & (5) \\
\hline & Imports & Imports & Imports & Imports & Imports \\
\hline \multirow[t]{2}{*}{ Capital 2000 BC-0 AD } & $0.053 * * *$ & $0.066 * * *$ & $0.037 *$ & $0.054 * * *$ & $0.037 * *$ \\
\hline & $(0.019)$ & $(0.019)$ & $(0.019)$ & $(0.019)$ & $(0.019)$ \\
\hline \multirow[t]{2}{*}{ Capital 0 AD-500 AD } & 0.018 & $0.027 *$ & 0.014 & 0.018 & 0.007 \\
\hline & $(0.016)$ & $(0.016)$ & $(0.016)$ & $(0.016)$ & $(0.016)$ \\
\hline \multirow[t]{2}{*}{ Capital 500 AD-1000 AD } & 0.005 & 0.007 & -0.011 & 0.005 & -0.002 \\
\hline & $(0.011)$ & $(0.011)$ & $(0.011)$ & $(0.011)$ & $(0.011)$ \\
\hline \multirow[t]{2}{*}{ Capital 1000 AD-1500 AD } & $0.039 * * *$ & $0.034 * * *$ & 0.018 & $0.035^{* * *} *$ & $0.030 * * *$ \\
\hline & $(0.012)$ & $(0.012)$ & $(0.012)$ & $(0.011)$ & $(0.012)$ \\
\hline \multirow[t]{2}{*}{ Capital 1500 AD-2000 AD } & $0.072 * * *$ & $0.031 * * *$ & $0.044 * * *$ & $0.050 * * *$ & $0.067 * * *$ \\
\hline & $(0.012)$ & $(0.012)$ & $(0.012)$ & $(0.012)$ & $(0.012)$ \\
\hline \multirow[t]{2}{*}{ Distance } & $-1.834 * * *$ & & & $-1.824 * * *$ & $-2.041 * * *$ \\
\hline & $(0.041)$ & & & $(0.040)$ & $(0.045)$ \\
\hline \multirow[t]{2}{*}{ Trek hours } & & $-1.508 * * *$ & & & \\
\hline & & $(0.033)$ & & & \\
\hline \multirow[t]{2}{*}{ Trek and sail hours } & & & $-1.630^{* * *}$ & & \\
\hline & & & $(0.046)$ & & \\
\hline \multirow[t]{2}{*}{ Trek obstacles } & & & & $-0.897 * * *$ & \\
\hline & & & & $(0.059)$ & \\
\hline \multirow[t]{2}{*}{ Trek obstacles and bad winds } & & & & & $-0.595 * * *$ \\
\hline & & & & & $(0.059)$ \\
\hline \multirow[t]{2}{*}{ Contiguity } & $0.885 * * *$ & $1.000 * * *$ & $0.986^{* * * *}$ & $0.861 * * *$ & $0.784 * * *$ \\
\hline & $(0.137)$ & $(0.138)$ & $(0.143)$ & $(0.136)$ & $(0.136)$ \\
\hline \multirow[t]{2}{*}{ Latitude diff. } & -0.018 & $-0.141 * * *$ & $-0.193 * * *$ & $-0.055^{* * *}$ & -0.026 \\
\hline & $(0.016)$ & $(0.015)$ & $(0.016)$ & $(0.016)$ & $(0.016)$ \\
\hline \multirow[t]{2}{*}{ Longitude diff. } & 0.014 & -0.019 & $-0.318 * * *$ & $0.071 * * *$ & 0.009 \\
\hline & $(0.021)$ & $(0.021)$ & $(0.020)$ & $(0.022)$ & $(0.021)$ \\
\hline $\mathrm{N}$ & 26808 & 26466 & 26808 & 26466 & 26808 \\
\hline R-sq & 0.80 & 0.81 & 0.80 & 0.81 & 0.81 \\
\hline
\end{tabular}

Importer and exporter fixed effects included in all regressions. Standard errors in parenthesis clustered by country-pair, and * stands for statistical significance at the $10 \%$ level, $* *$ at the $5 \%$ level and $* * *$ at the $1 \%$ percent level

in this specification, out of 155 empires, 75 have positive effects on trade, 80 have a negative one, and the mean effect is zero. This specification also makes it hard to identify the separate effects of empires which covered similar territories but over different periods, as these empire dummies are highly correlated. Overall, this reinforces our dynamic imperial capital methodology which allows us to capture the aggregate effect of successive empires. 


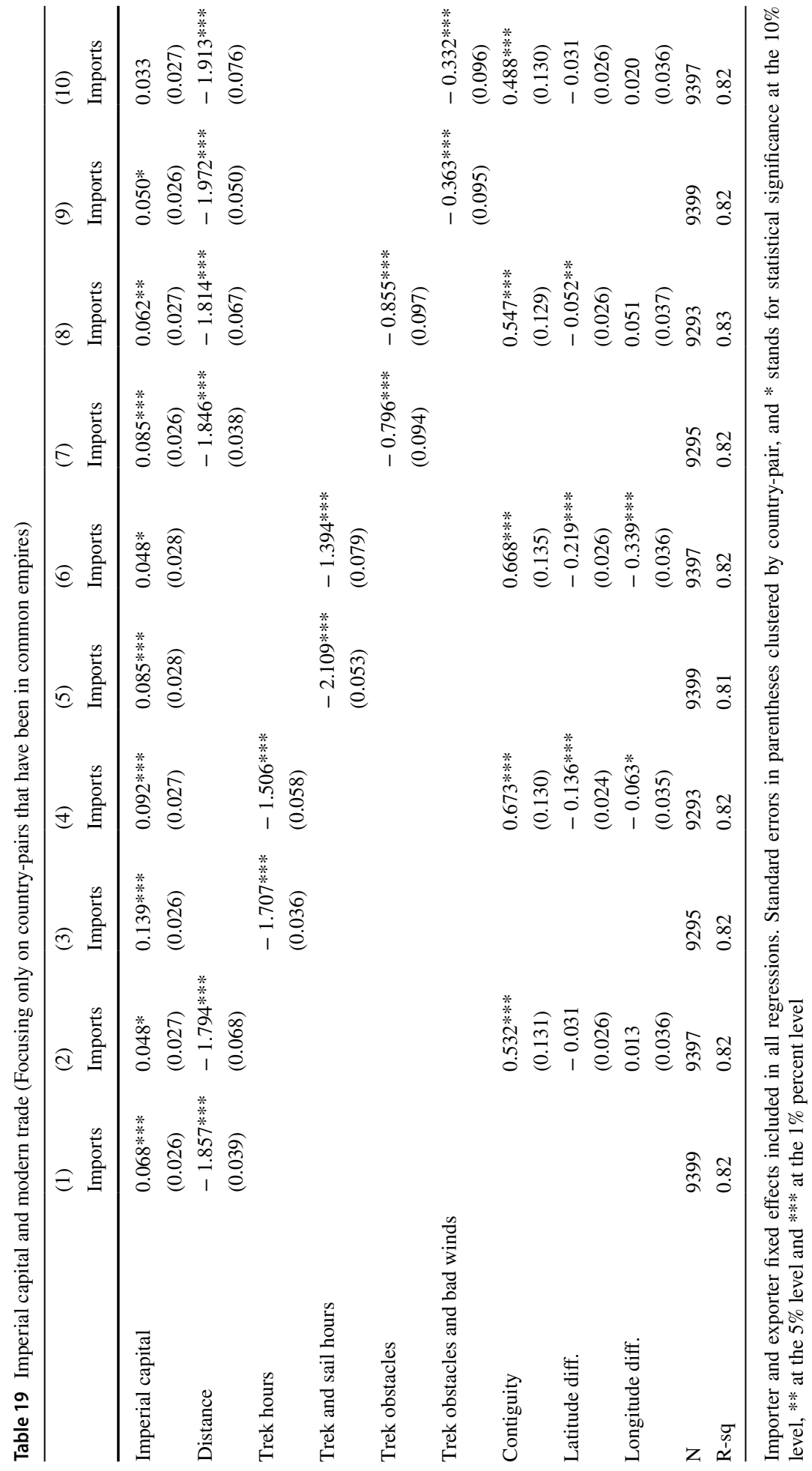




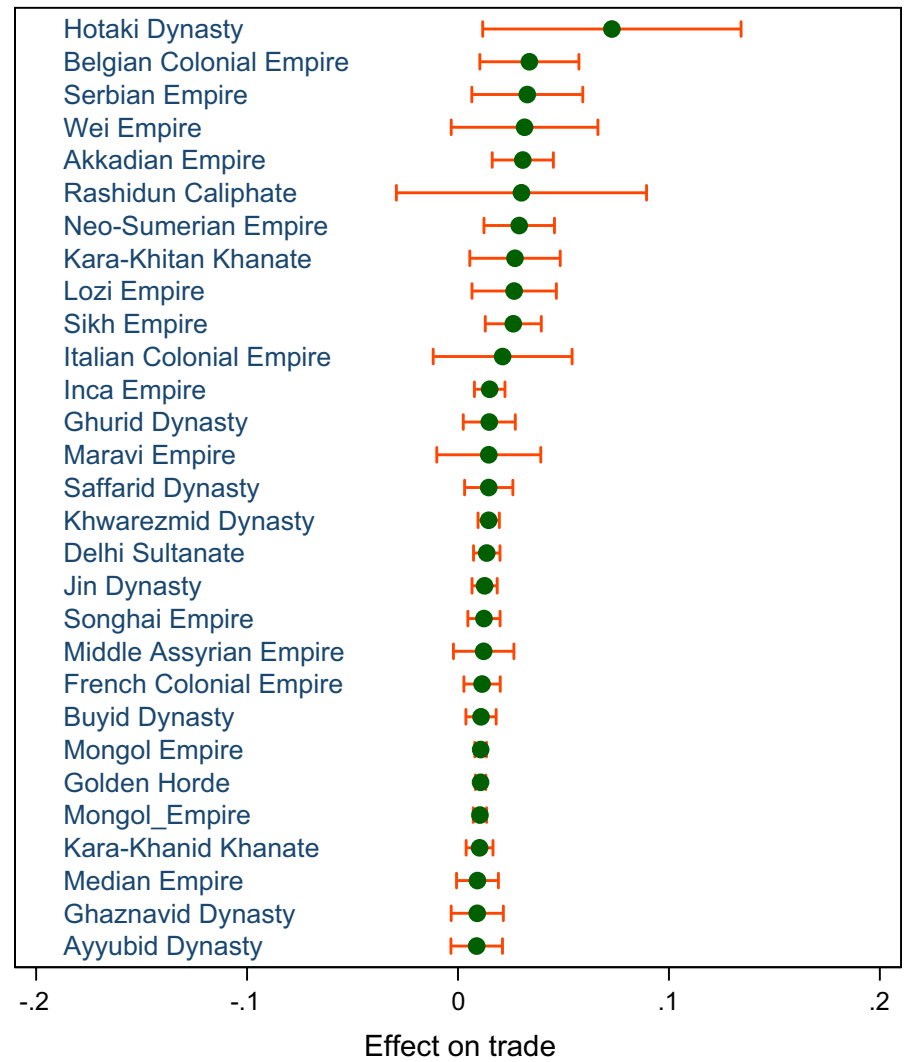

Fig. 8 Top 30 empire effects. Notes The effect of individual empires are estimated in a specification akin to that in column (1) of Table 3

\section{Appendix 2: Further details on bilateral distance measures}

Once you have ships, tunnels, canals, cars, and trains, human mobility becomes more and more correlated with geodesic distance, which is the standard control in gravity regressions. One reason it is the standard is that geodesic distance is an exogenous measure of trade costs. It captures many bilateral obstacles other than transport costs which can be endogenous to trade and to technological developments. Indeed, it captures information and cultural frictions even when technology allows you to go everywhere. Yet, our current geographic measures of human mobility allow us to show that natural obstacles such as ruggedness and bad winds still have an impact on trade. They also allow us to capture geographic determinants of empire expansion. Indeed, it is clear that wind direction played a key role before steam power in determining why countries were more likely to trade and become part of empires (Feyrer and Sacerdote 2009; Pascali 2017). Geodesic distance on the other hand does not really explain European colonization patterns. For these reasons, we think our human mobility variables are quite useful in our context. Below, we provide summary statistics showing how human mobility relates to geodesic distance. The code to replicate the human mobility measures is available here: https://www.wnvermeulen.com/ empires/routing_tutorial.html 


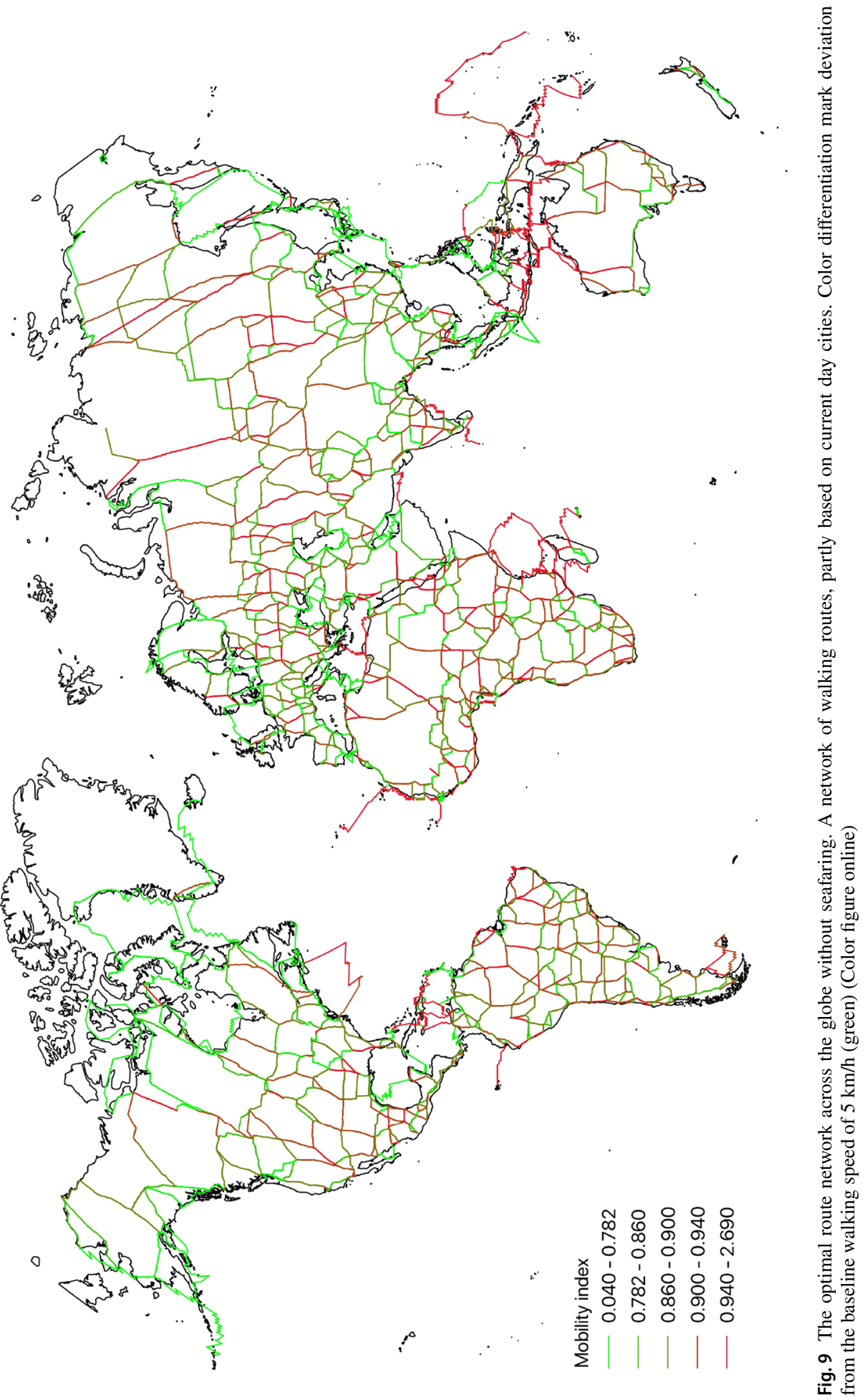




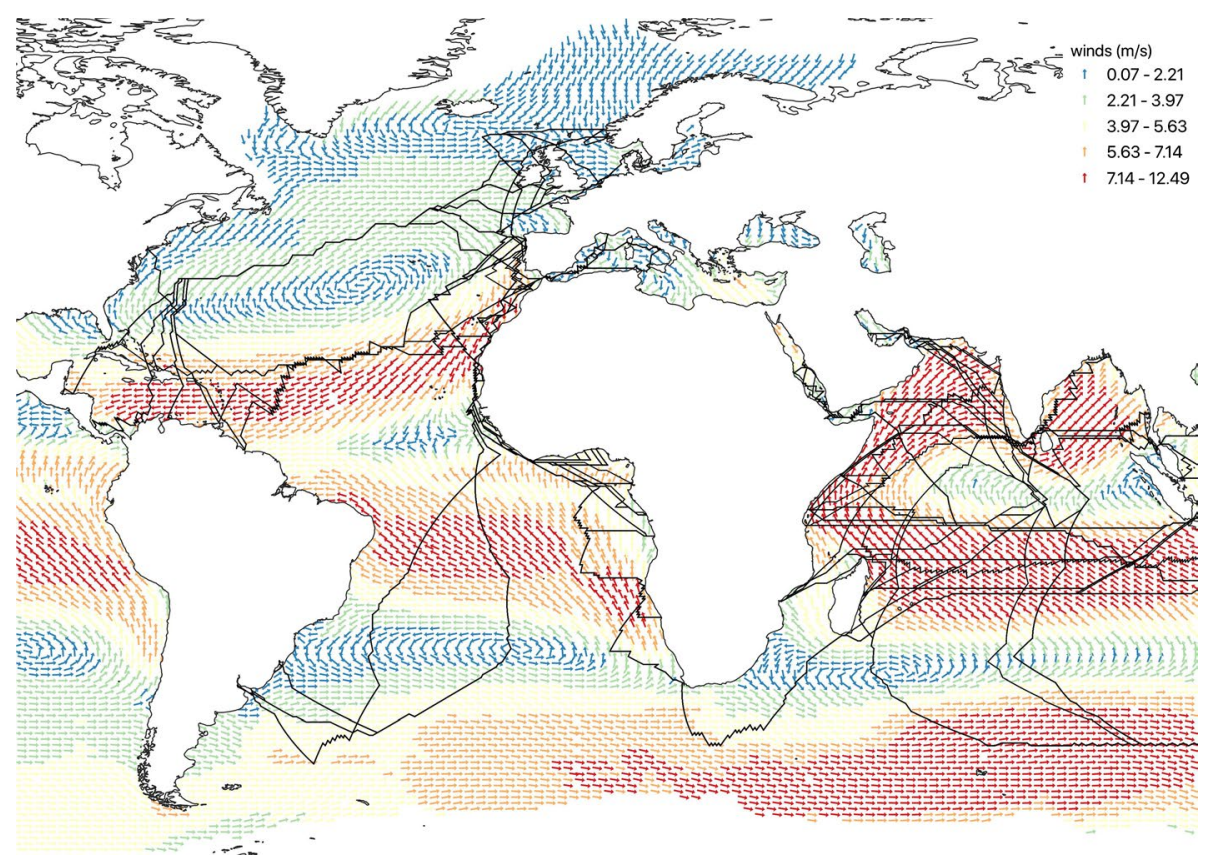

Fig. 10 Major shipping routes and wind patterns. A selection of optimal sailing routes across oceans, with indicators of prevailing wind speed and wind direction. The optimal route takes into account the prevailing wind speed, wind direction and the angle of sailing relative to the wind direction. Information on global ocean winds come from NASA (2012). The sailing speeds given wind are taken from Pascali (2017). Routes were selected between continents, e.g. from Europe to America and Africa, and Africa to Asia. So the fastest voyage from Europe to Asia would go through South Africa. Voyages in the Pacific Ocean are allowed but not indicated in the figure

We differentiate between two historic distance measures, one where sailing is limited to within $200 \mathrm{~km}$ of coastlines, and one where this limitation is relaxed. The limitation prohibits cross-ocean links which effectively captures the barriers that oceans formed until technological advances for such voyages had been reached in the 16th century.

Figure 9 gives an overview of the optimal route network we estimate without seafaring. The shades of the routes vary from red (slow) to green (fast). Generally, we see that mountainous regions imply a slower walking speed or large detours. Figure 10 shows a selection of optimal sailing routes across oceans, with indicators of prevailing wind speed and wind direction. The optimal route takes into account the prevailing wind speed, wind direction and the angle of sailing relative to the wind direction. Information on global ocean winds come from NASA (2012). The sailing speeds given wind are taken from Pascali (2017). Routes were selected between continents, e.g. from Europe to America and Africa, and Africa to Asia. So the fastest voyage from Europe to Asia would go through South Africa. Voyages in the Pacific Ocean are allowed but not indicated in the figure.

Our measures of geographic barriers to human mobility are thus the number of hours it would take a human to trek across lands, or sail across oceans, via these optimal routes. As shown in Fig. 11, travel hours are correlated with 'as the crow flies' distance. And, at large distances, seafaring reduces travel time by a large factor. Importantly this 


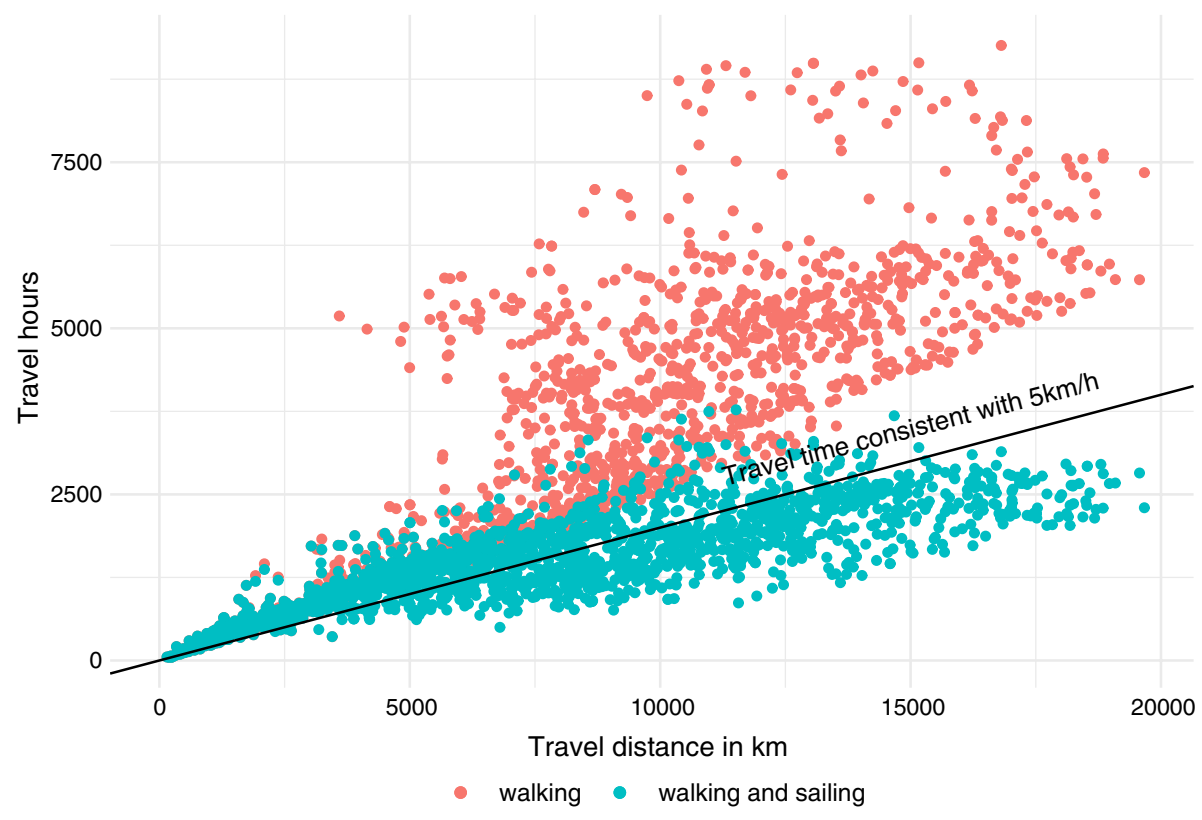

Fig. 11 Geodesic versus travel hours. The $5 \mathrm{~km} / \mathrm{h}$ line simply divides the number of kilometers on the $\mathrm{x}$-axis by 5 to find the corresponding number of travel hours

correlation is not uniform over distances, as presented in Fig. 12. At longer distances, geographic obstacles matter less as they can be avoided, and this is especially true with seafaring. Thus, travel hours over long distance are quite correlated with geodesic distance. On the other hand, geographic obstacles such as mountains might have a large effect on travel hours over short distances, reducing the correlation between travel hours and distance.

We observe a high correlation at short distances, probably, as those observations consist of routes with few geographic obstacles. Over large distances, we observe a big difference in correlations with and without seafaring. This is because walking distances are largely affected by water bodies over larger distances and having to take a giant detour around an ocean will create a big discrepancy between walking and 'flying'. The ability to sail, therefore, allows to get relatively closer to the 'flying' distance.

\section{Appendix 3: Empires, characteristics, countries and dates}

In Table 20, we present the dataset we collected using numerous sources and with the help of many historians. Full sources are available online, including a more convenient data structure for download and future research, at https://www.wnvermeulen.com/empir es/. The table is sorted chronologically by starting date of Empire. An asterisk indicates the country that contains the capital, or metropole or administrative center, of the empire.

The three characteristics 'King', 'God', and 'Coin' indicate answers to the following questions. 


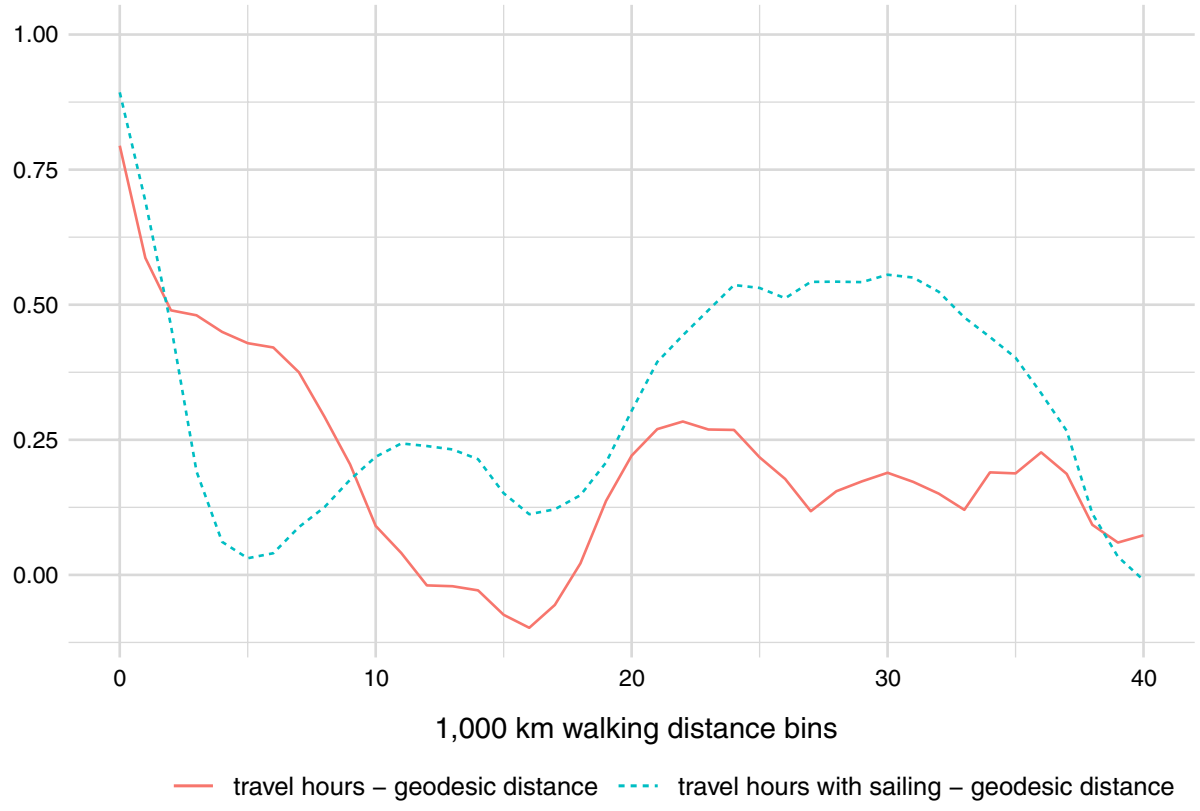

Fig. 12 Correlations between geodesic and travel hours by distance bins

King: Does the empire have an absolute ruler, at least nominally? This acknowledges that real political power may be more diffuse in reality. Most empires would have this property.

God: Did the empire have a centralised religion, where the ruler, at least nominally, drew power from or was head of the religion within its territory? This does not necessitates that other religions are not allowed within the empire. All caliphates and some European empires are designated as such.

Coin: Did the empire have a central mint controlled by the ruler.

See the main text for the reasoning behind these three characteristics. 


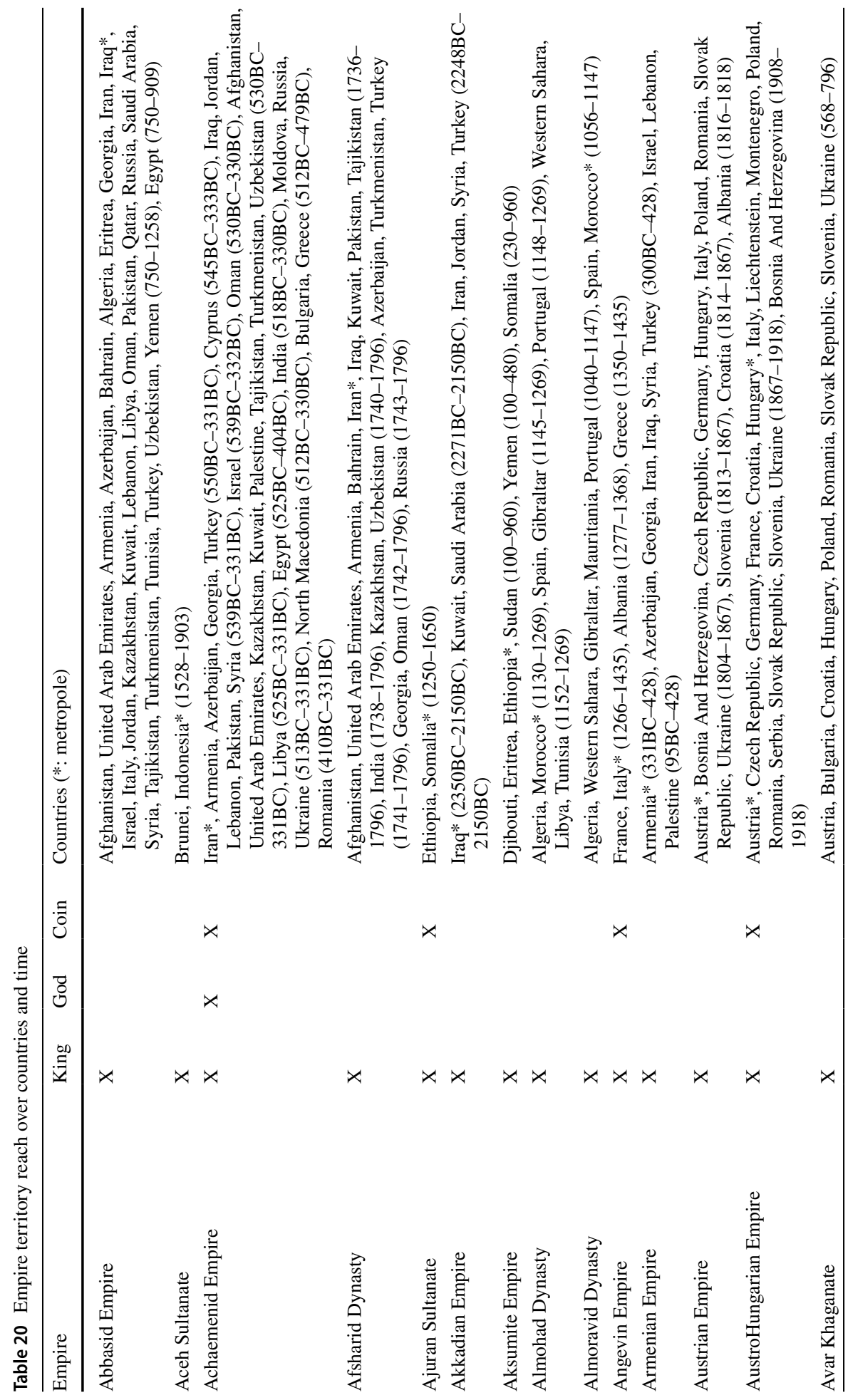




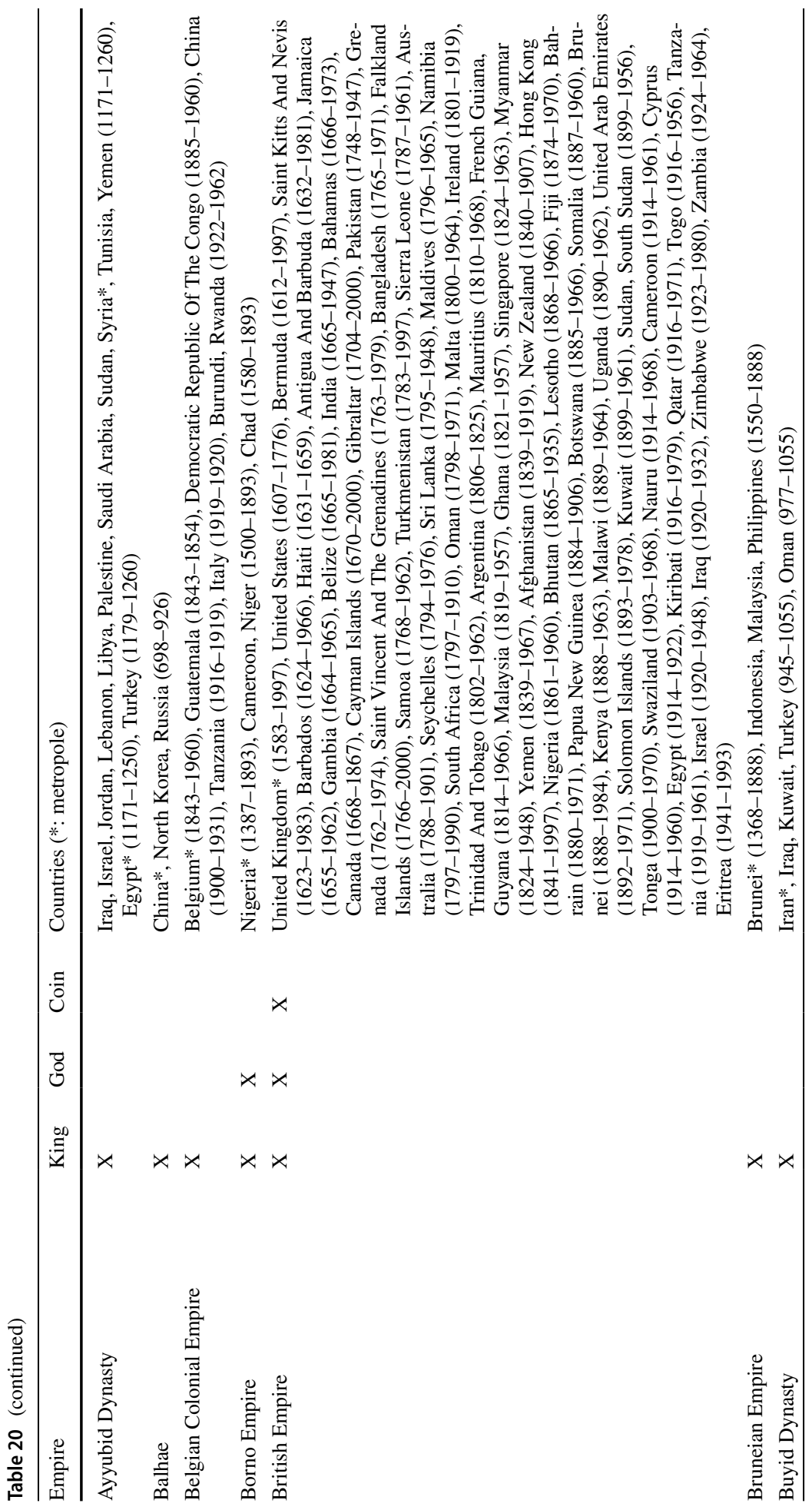




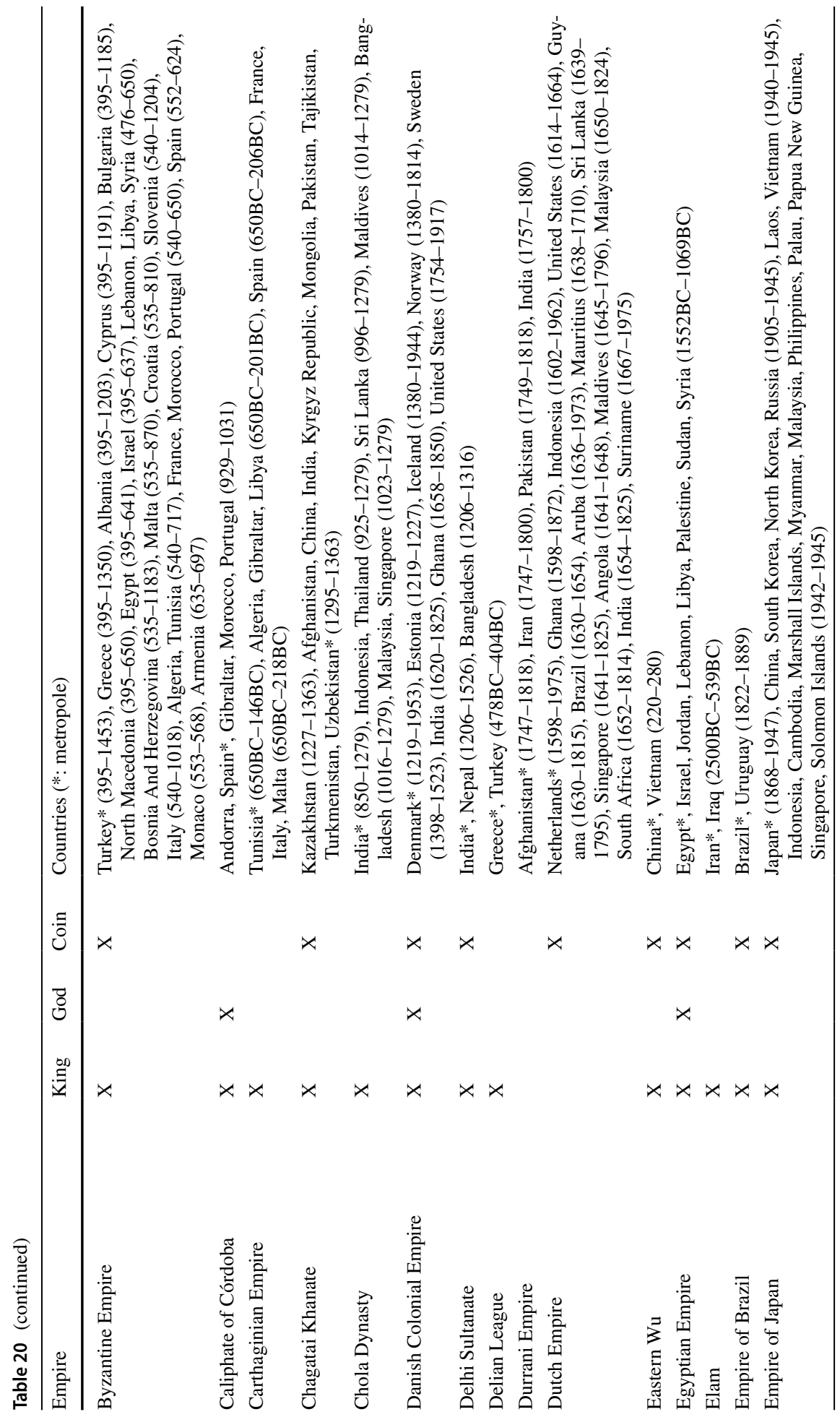




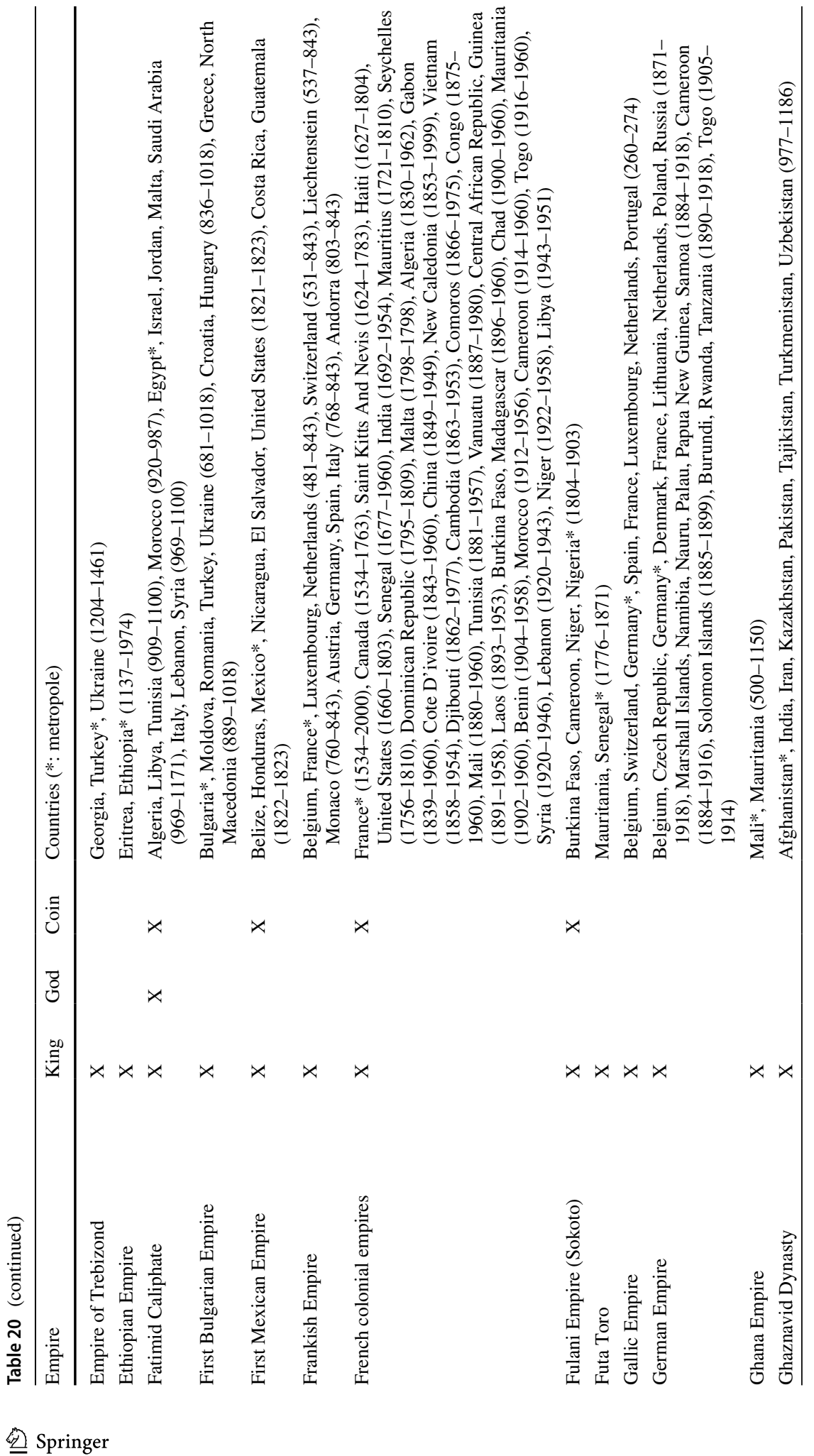




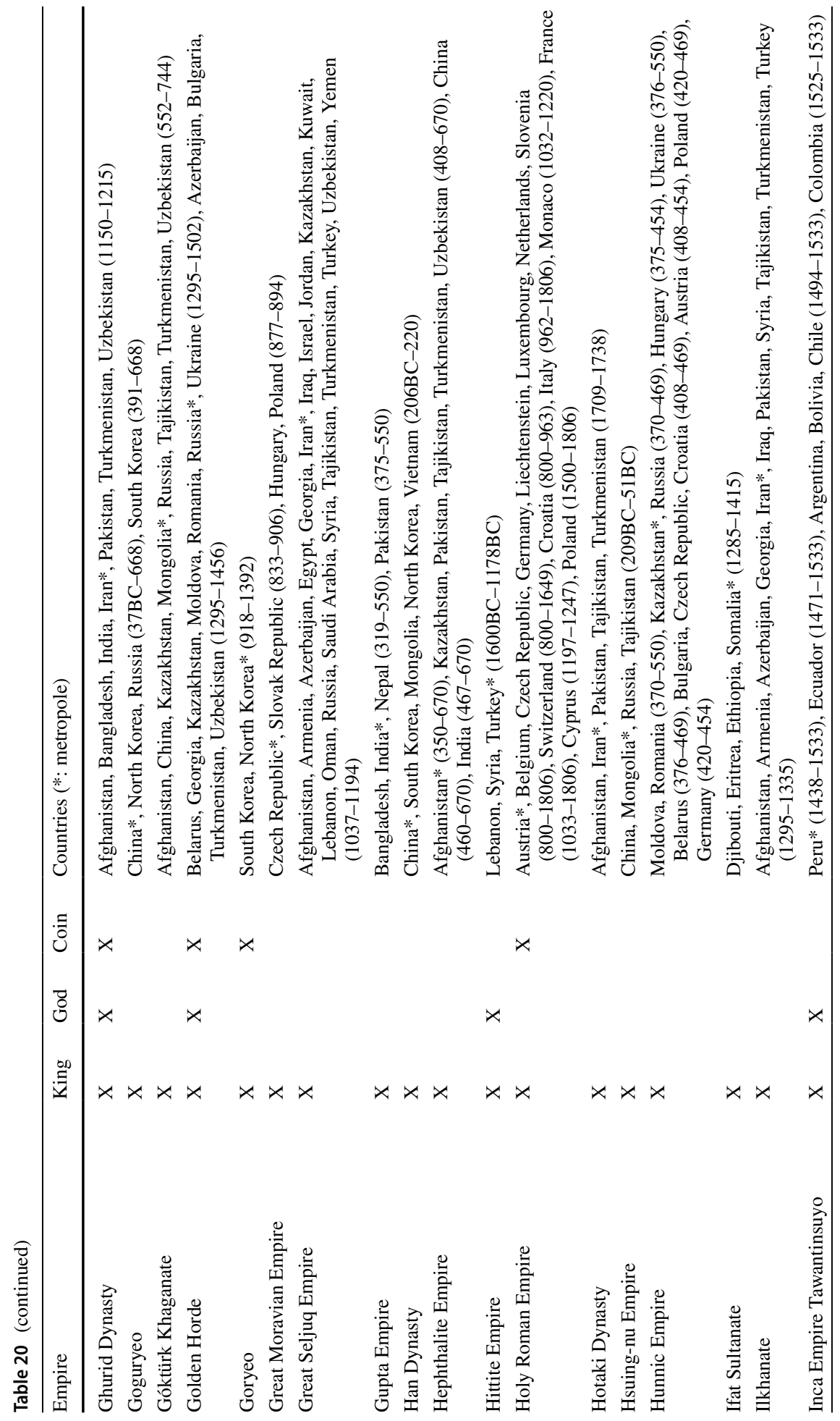




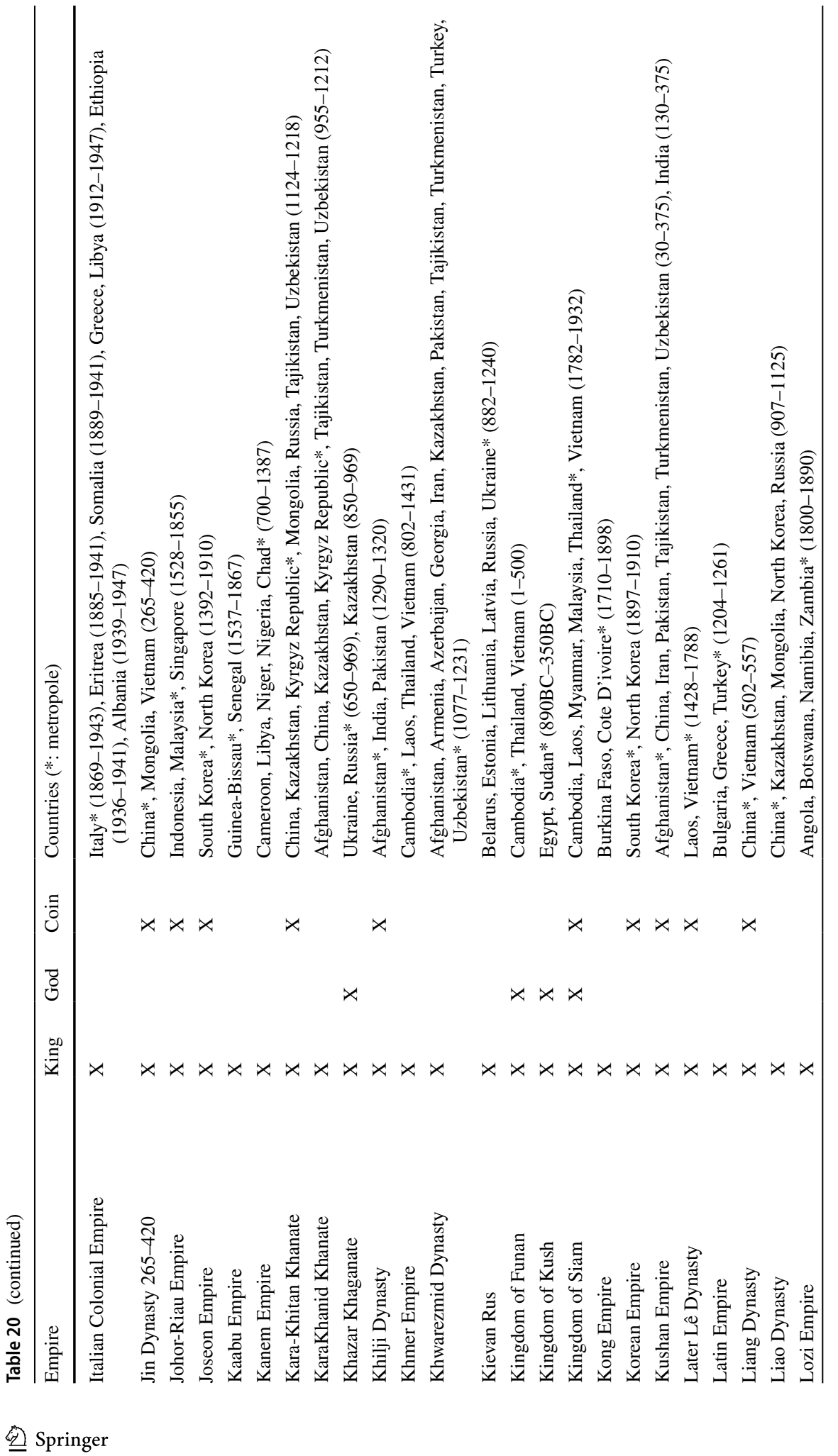




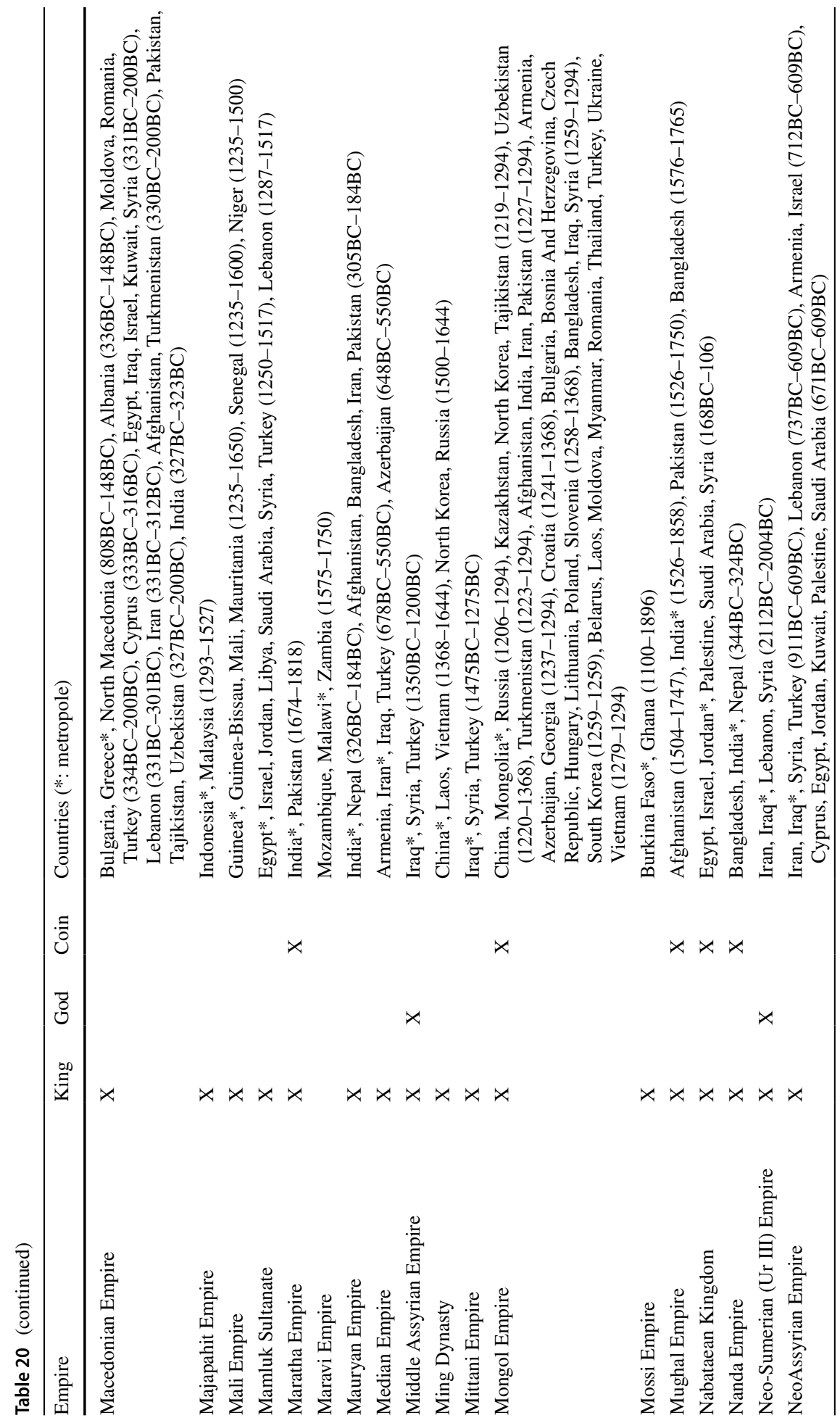




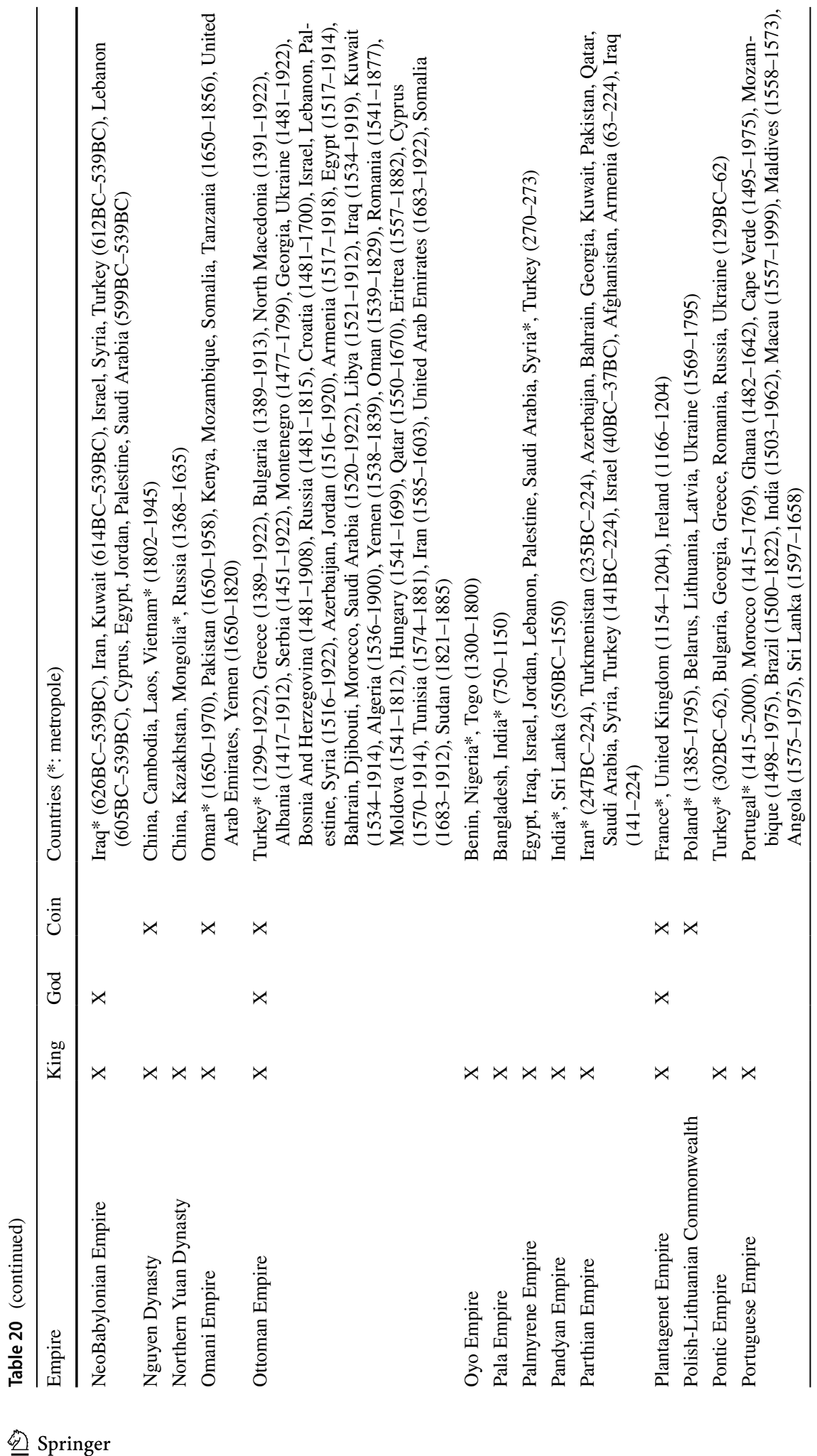




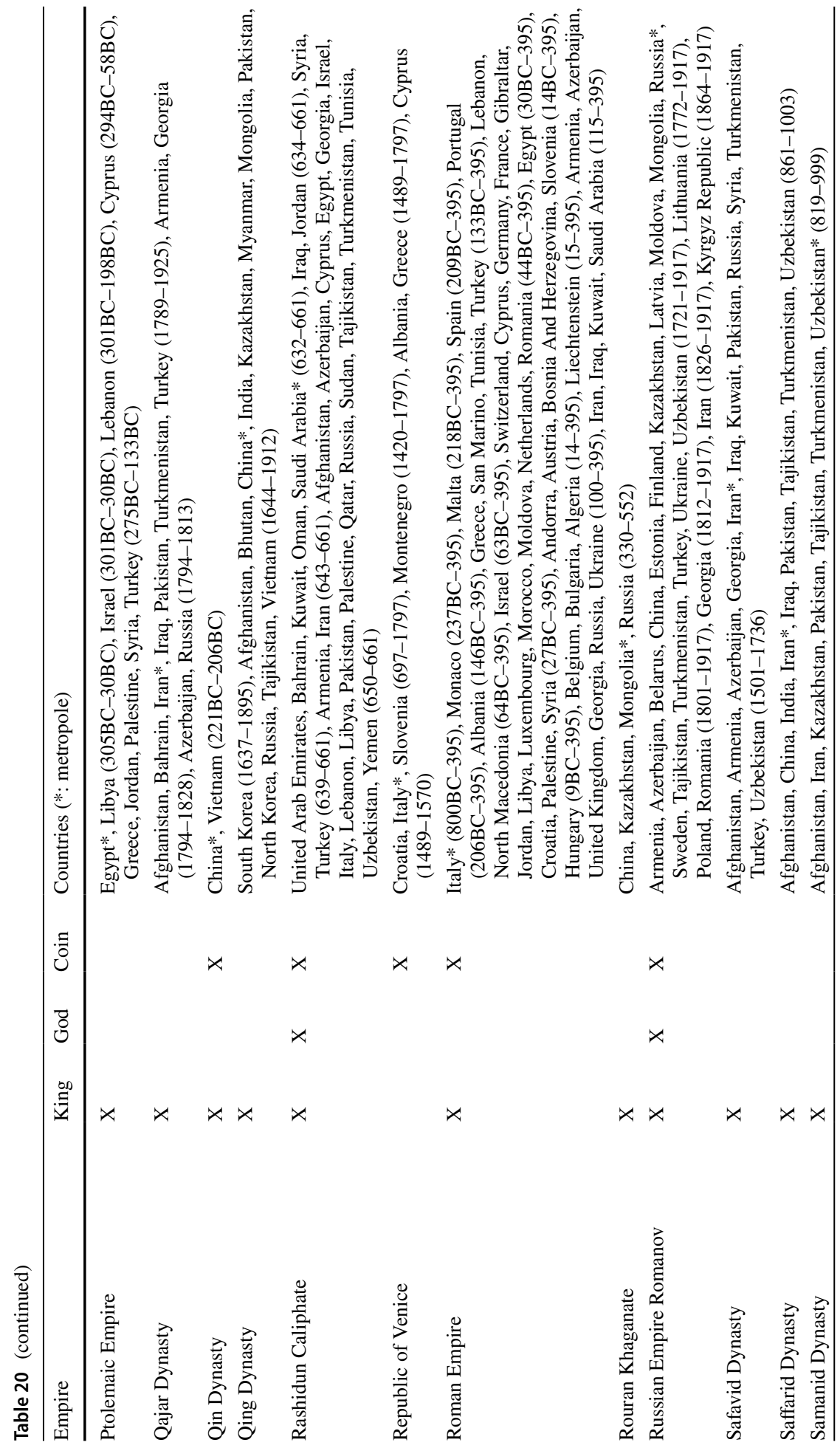




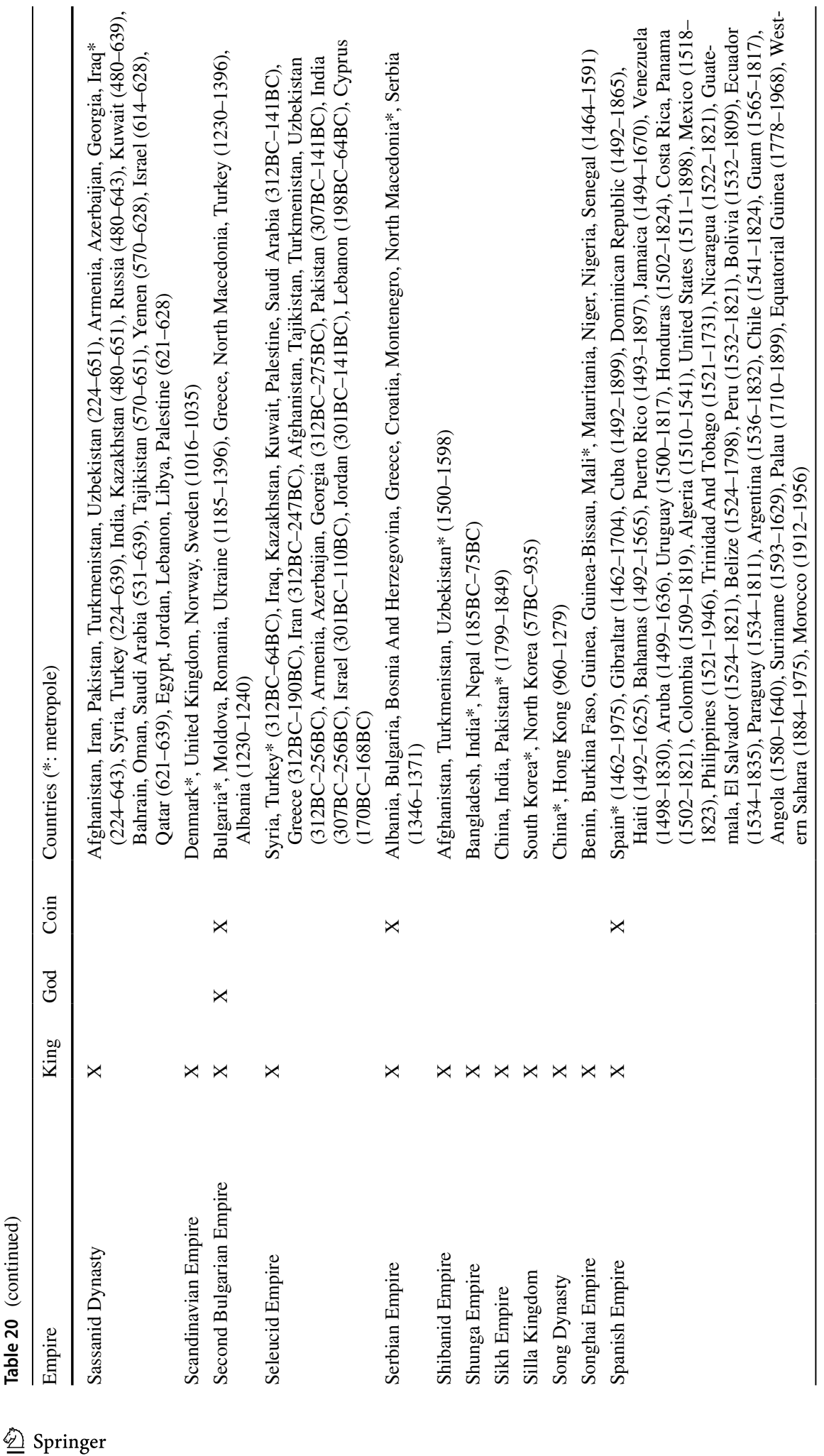




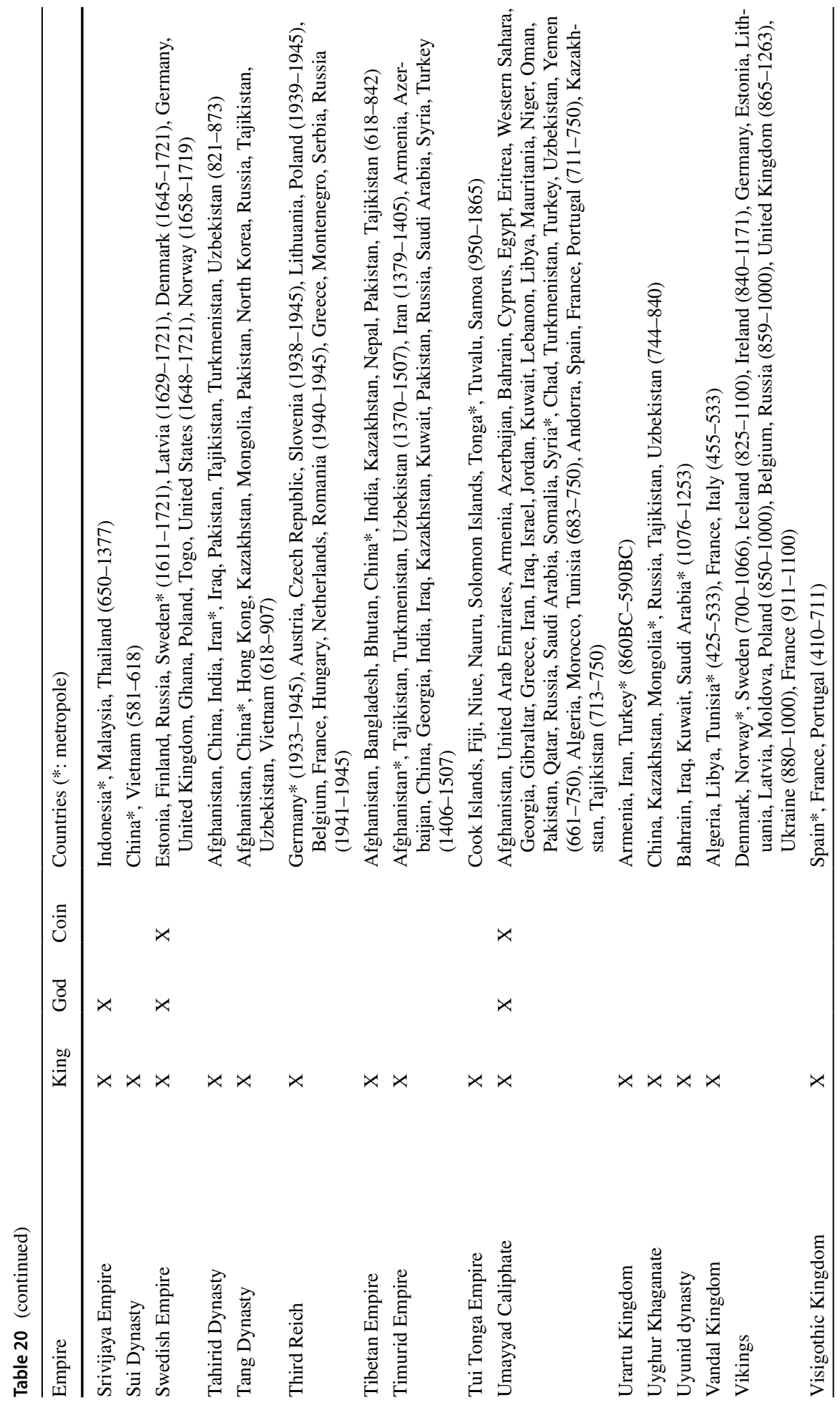




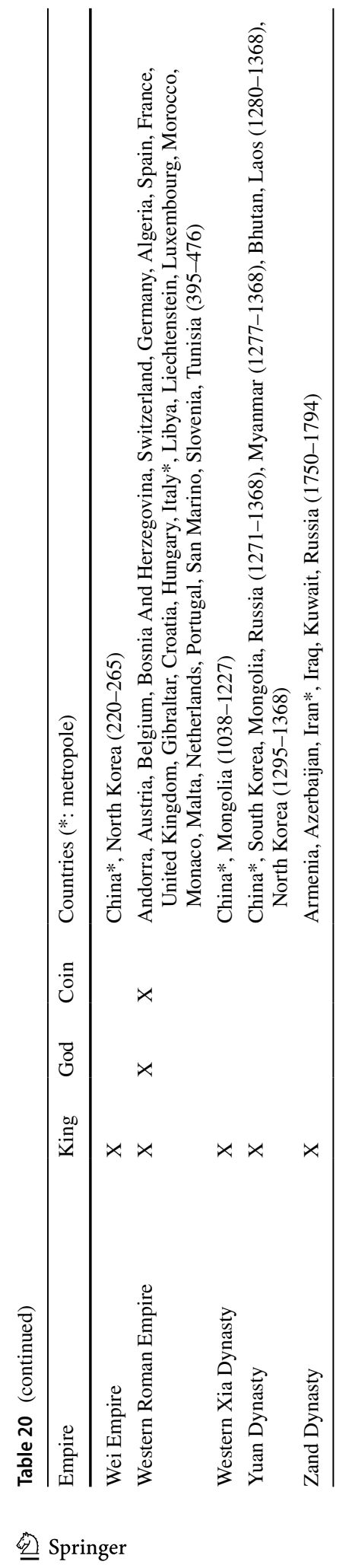




\section{References}

Abadie, A., Athey, S., Imbens, G. W., \& Wooldridge, J. (2017). When should you adjust standard errors for clustering? Working paper 24003, National Bureau of Economic Research.

Acemoglu, D., Johnson, S., \& Robinson, J. A. (2001). The colonial origins of comparative development: An empirical investigation. American Economic Review, 91(5), 1369-1401.

Afandiyeva, V. (2018). Rus' raiding in the Caspian region and the Norman theory. Gilea: A Scientific Bulletin, 133, 77-81.

Alesina, A., Spolaore, E., \& Wacziarg, R. (2000). Economic integration and political disintegration. American Economic Review, 90(5), 1276-1296.

Ashraf, Q., Galor, O., \& Özak, Ö. (2010). Isolation and development. Journal of the European Economic Association, 8(2-3), 401-412.

Becker, S. O., Boeckh, K., Hainz, C., \& Woessmann, L. (2016). The empire is dead, long live the empire! Long-run persistence of trust and corruption in the bureaucracy. The Economic Journal, 126(590), 40-74.

Bernstein, W. (2008). A splendid exchange: How trade shaped the world. New York: Atlantic Monthly Press.

Bockstette, V., Chanda, A., \& Putterman, L. (2002). States and markets: The advantage of an early start. Journal of Economic Growth, 7, 347-369.

Borcan, O., Olsson, O., \& Putterman, L. (2018). State history and economic development: Evidence from six millennia. Journal of Economic Growth, 23(1), 1-40.

Burbidge, J. B., Magee, L., \& Robb, A. L. (1988). Alternative transformations to handle extreme values of the dependent variable. Journal of the American Statistical Association, 83(401), 123-127.

Card, D., \& DellaVigna, S. (2017). What do editors maximize? Evidence from four leading economics journals. Working paper 23282, National Bureau of Economic Research.

Chor, D. (2010). Unpacking sources of comparative advantage: A quantitative approach. Journal of International Economics, 82(2), 152-167.

Davis, D. (2000). Understanding international trade patterns: Advances of the 1990s. Integration and Trade, 4, 61-79.

Davis, D. R., \& Weinstein, D. E. (2003). Why countries trade: Insights from firm-level data. Journal of the Japanese and International Economies, 17(4), 432-447.

Donaldson, D. (2018). Railroads of the Raj: Estimating the impact of transportation infrastructure. American Economic Review, 108(4-5), 899-934.

Easterly, W., \& Levine, R. (2016). The European origins of economic development. Journal of Economic Growth, 21(3), 225-257.

Eichengreen, B., \& Irwin, D. A. (1998). The role of history in bilateral trade flows. In The regionalization of the world economy, NBER chapters (pp. 33-62). National Bureau of Economic Research, Inc.

Felbermayr, G. J., \& Toubal, F. (2010). Cultural proximity and trade. European Economic Review, 54(2), 279-293.

Feyrer, J. (2009). Distance, trade, and income: The 1967 to 1975 closing of the Suez Canal as a natural experiment. NBER working papers 15557, National Bureau of Economic Research, Inc.

Feyrer, J., \& Sacerdote, B. (2009). Colonialism and modern income: Islands as natural experiments. The Review of Economics and Statistics, 91(2), 245-262.

Findlay, R., \& O'Rourke, K. (2009). Power and plenty: Trade, war, and the world economy in the second millennium. The Princeton economic history of the western world. Princeton: Princeton University Press.

Fluckiger, M., Hornung, E., Larch, M., Ludwig, M., \& Mees, A. (2019). Roman transport network connectivity and economic integration. CESifo working paper series 7740, CESifo Group Munich.

Galor, O. (2011). Unified growth theory. Princeton: Princeton University Press.

Gokmen, G. (2017). Clash of civilizations and the impact of cultural differences on trade. Journal of Development Economics, 127(C), 449-458.

Greif, A. (2006). Institutions and the path to the modern economy: Lessons from medieval trade. Political economy of institutions and decisions. Cambridge: Cambridge University Press.

Grosfeld, I., \& Zhuravskaya, E. (2015). Cultural vs. economic legacies of empires: Evidence from the partition of Poland. Journal of Comparative Economics, 43(1), 55-75.

Grosjean, P. (2011). The weight of history on European cultural integration: A gravity approach. American Economic Review, 101(3), 504-08.

Head, K., \& Mayer, T. (2013). What separates us? Sources of resistance to globalization. Canadian Journal of Economics, 46(4), 1196-1231. 
Head, K., \& Mayer, T. (2014). Gravity equations: Workhorse, toolkit, and cookbook, volume 4 of handbook of international economics, chapter 3 (pp. 131-195). Amsterdam: Elsevier.

Head, K., Mayer, T., \& Ries, J. (2010). The erosion of colonial trade linkages after independence. Journal of International Economics, 81(1), 1-14.

Huning, T. R., \& Wahl, F. (2016). You reap what you know: Observability of soil quality, and political fragmentation. Working papers 0101, European Historical Economics Society (EHES).

Jha, S. (2013). Trade, institutions, and ethnic tolerance: Evidence from South Asia. American Political Science Review, 107, 806-832.

Kristjánsdóttir, H. (2012). Exports from a remote developed region: Analysed by an inverse hyperbolic sine transformation of the gravity model. The World Economy, 35(7), 953-966.

Laiou, A., \& Morrisson, C. (2007). The Byzantine economy. Cambridge medieval textbooks. Cambridge: Cambridge University Press.

Lopez, R. S. (1951). The dollar of the middle ages. The Journal of Economic History, 11(3), 209-234.

Mackenzie, J. (2016). The encyclopedia of empire, 4 volume set. New York: Wiley.

MacKinnon, J. G., \& Magee, L. (1990). Transforming the dependent variable in regression models. International Economic Review, 31(2), 315-339.

Mayer, T., \& Zignago, S. (2011). Notes on cepii's distances measures: The geodist database. Working papers 2011-25, CEPII.

Mayshar, J., Moavz, O., Neeman, Z., \& Pascali, L. (2016). Cereals, appropriability and hierarchy. Economic research papers 269316, University of Warwick-Department of Economics.

Melitz, J., \& Toubal, F. (2014). Native language, spoken language, translation and trade. Journal of International Economics, 93(2), 351-363.

Michaels, G. (2008). The effect of trade on the demand for skill: Evidence from the interstate highway system. The Review of Economics and Statistics, 90(4), 683-701.

Michalopoulos, S., \& Papaioannou, E. (2017). The long economic and political shadow of history. CEPR ebook.

Mitchener, K. J., \& Weidenmier, M. (2008). Trade and empire. The Economic Journal, 118(533), 1805-1834.

NASA. (2012). QuickScat, wind speed. Technical report. https://opendap.jpl.nasa.gov/opendap/hyrax/allDa ta/quikscat/L3/wind_1deg_1mo/contents.html.

Nunn, N. (2008). The long-term effects of Africa's slave trades. The Quarterly Journal of Economics, 123(1), 139-176.

Nunn, N. (2009). The importance of history for economic development. Annual Review of Economics, 1(1), 65-92.

Oto-Peralías, D., \& Romero-Ávila, D. (2016). The economic consequences of the Spanish Reconquest: The long-term effects of Medieval conquest and colonization. Journal of Economic Growth, 21(4), 409-464.

Özak, Ö. (2010). The voyage of homo-œconomicus: Some economic measures of distance. Unpublished manuscript.

Özak, Ö. (2018). Distance to the pre-industrial technological frontier and economic development. Journal of Economic Growth, 23(2), 175-221.

Pascali, L. (2017). The wind of change: Maritime technology, trade, and economic development. American Economic Review, 107(9), 2821-54.

Pinna, A., \& Licio, V. (2017). The long-term effects of the historical Roman road network: Trade costs. Working paper, Centre for North South Economic Research, University of Cagliari and Sassari, Sardinia.

Putterman, L., \& Weil, D. N. (2010). Post-1500 population flows and the long-run determinants of economic growth and inequality. Quarterly Journal of Economics, 125(4), 1627-1682.

Rauch, F., \& Beestermoller, M. (2014). A dissection of trading capital: Cultural persistence of trade in the aftermath of the fall of the Iron Curtain. Economics series working papers 718, University of Oxford, Department of Economics.

Rauch, J. E. (1999). Networks versus markets in international trade. Journal of International Economics, $48(1), 7-35$.

Rauch, J. E. (2001). Business and social networks in international trade. Journal of Economic Literature, 39(4), 1177-1203.

Rauch, J. E., \& Trindade, V. (2002). Ethnic Chinese networks in international trade. The Review of Economics and Statistics, 84(1), 116-130.

Spolaore, E., \& Wacziarg, R. (2013). How deep are the roots of economic development? Journal of Economic Literature, 51(2), 325-69. 
Steinwender, C. (2018). Real effects of information frictions: When the states and the kingdom became united. American Economic Review, 108(3), 657-96.

The Economist. (2008). The greatest journey. The Economist. July 17, 2008.

Tinbergen, J. (1962). Shaping the world economy: Suggestions for an international economic policy. New York: Twentieth Century Fund.

Turchin, P. (2009). A theory for formation of large empires. Journal of Global History, 4(2), 191-217.

Turchin, P., Adams, J., \& Hall, T. (2006). East-west orientation of historical empires and modern states. Journal of World-Systems Research, 12(2), 219-229.

Volpe Martincus, C., Carballo, J., \& Cusolito, A. (2017). Roads, exports and employment: Evidence from a developing country. Journal of Development Economics, 125, 21-39.

Wahl, F. (2016). Does medieval trade still matter? Historical trade centers, agglomeration and contemporary economic development. Regional Science and Urban Economics, 60, 50-60.

Wahl, F. (2017). Does European development have Roman roots? Evidence from the German Limes. Journal of Economic Growth, 22(3), 313-349.

Publisher's Note Springer Nature remains neutral with regard to jurisdictional claims in published maps and institutional affiliations. 